\title{
Inorganic Nanoparticles in Cancer Therapy
}

\author{
Sanjib Bhattacharyya ${ }^{1}$, Rachel A. Kudgus ${ }^{1}$, Resham Bhattacharya ${ }^{1}$, and Priyabrata \\ Mukherjee ${ }^{1,2,3,{ }^{*}}$ \\ ${ }^{1}$ Department of Biochemistry and Molecular Biology, Mayo Clinic College of Medicine, \\ Rochester, MN 55905 \\ 2 Department of Physiology and Biomedical Engineering, Mayo Clinic College of Medicine, \\ Rochester, MN 55905 \\ ${ }^{3}$ Mayo Clinic Cancer Center, Mayo Clinic College of Medicine, Rochester, MN 55905
}

\section{Abstract}

Nanotechnology is an evolving field with enormous potential for biomedical applications. The growing interest to use inorganic nanoparticles in medicine is due to the unique size and shapedependent optoelectronic properties. Herein, we will focus on gold, silver and platinum nanoparticles, discussing recent developments for therapeutic applications with regard to cancer in terms of nanoparticles being used as a delivery vehicle as well as therapeutic agents. We will also discuss some of the key challenges to be addressed in future studies.

\section{Introduction}

Nanotechnology is a flourishing area with several interdisciplinary fields, such as medicine, electronics, and biomaterials (1). The long-term goal of nanomedicine is to revolutionize the health care system by fighting deadly diseases in more efficient ways (1). Gold nanoparticles are being investigated for biological applications due to their biocompatibility $(1,2)$. In this review, we will focus on gold and a few other inorganic nanoparticles and discuss their potential applications in therapy and imaging. Gold nanoparticles have been used mostly as a probe for electron microscopy and as a delivery vehicle for biomolecules. However, the use of nanoparticles as a therapeutic agent is relatively new. Among all the nanomaterials, gold has attracted wide attention due to its relative non-toxic nature (2-5). Gold has been shown to have strong affinity to thiol and amine functionalities (2). Such affinity enables surface modifications to gold nanoparticles relatively easily through Au-S and $\mathrm{Au}-\mathrm{N}$ bonding with targeting agents and/or chemotherapeutics that possess these functionalities (2). Thus, through intelligent design it is possible to develop multifunctional nanoparticles that could potentially increase the efficiency of detection, diagnosis and therapy $(2,3)$.

\section{Application of Gold in Ancient Medicine}

Gold compounds were used by Chinese and Indian cultures as early as $2500-2600$ BC in the form of "Swarna Bhasma," a gold based medicine, for various purposes such as increasing vital power and curing male impotence (4-6). In the early $19^{\text {th }}$ and $20^{\text {th }}$ centuries gold compounds were utilized for the treatment of epilepsy, syphilis, rheumatic diseases,

\footnotetext{
*Corresponding Author: Priyabrata Mukherjee, Ph.D, Department of Biochemistry and Molecular Biology, Department of Biomedical Engineering, Cancer Center, Mayo Clinic, Rochester, MN-55905, mukherjee.priyabrata@ mayo.edu, Phone: 507-284-8563, Fax: 507-293-1058.
} 
tuberculosis, and various inflammatory skin diseases (7-9). Sodium aurothiomalate $\left(\right.$ Myocrisin $^{\mathrm{TM}}$ ) and aurothioglucose (Solganol ${ }^{\mathrm{TM}}$ ) are water soluble gold (I) complexes used for rheumatoid arthritis. A second generation gold drug, auranofin (Ridauro ${ }^{\mathrm{TM}}$ ) was developed in 1985; that demonstrated better efficacy in the treatment of arthritis (10-12). Furthermore, the potency of auranofin against leukemia (p388) cells in vivo initiated the screening of many bis(diphospho) gold (I) complexes, but the cardiovascular toxicity of the compound precluded its clinical use $(12,13)$. The proposed mechanism of action involves the conversion of gold (I) and gold (III) to gold (0); a possible active species under biological conditions.

In 1978 cisplatin was approved by the Food and Drug Administration as an antitumor agent. This application generated interest in exploring other metals for potential anti-cancer properties. Mainly, gold-based compounds demonstrated anti-cancer properties. The addition of gold (I) and gold (III) compounds enhanced the antitumor activity of the known antitumor compounds $(12,13)$. Recent evidence inspires the future application of gold nanoparticles as a therapeutic molecule in angiogenesis dependent disorders such as cancer and rheumatoid arthritis (14).

\section{Synthesis of Nanoparticles}

Preparation of gold nanoparticles (AuNP) of different sizes and shapes are well documented $(2,5,15,16)$. In brief, the AuNP can be synthesized in three different ways; (a) physical methods, (b) chemical methods and (c) biological methods. Physical methods include microwave irradiation (17), sonochemical method (18), Ultra-Violet irradiation (19), laser ablation (20), thermolytic process (21), photochemical and radical induced methods $(22,23)$. Chemical processes for nanoparticle syntheses are widely used. Michael Faraday pioneered the synthesis of colloidal gold as early as 1857 ; he described the synthesis by reducing gold chloride in a carbon disulfide solvent using phosphorous as a reducing agent (24). Generally, AuNPs are produced in solution phase synthesis utilizing hydrogen tetrachloroaurate $\left(\mathrm{HAuCl}_{4}\right)$ as the metal precursor followed by a reduction step with sodium borohydride, trisodium citrate, or phosphorous (25). Citrate can act as a reducing agent and as a stabilizer of AuNPs by capping the nanoparticle surface and preventing aggregation (26). Many AuNPs are capped in a mono-layer protected fashion; the mono-layer is often composed of thiols. Typically these particles are formed using the $\mathrm{NaBH}_{4}$ reduction of $\mathrm{HAuCl}_{4}$ in the presence of nearly any thiolated ligand, sometimes tetraoctylammonium bromide (TOAB) is introduced as a phase transfer catalyst (27). Other chemical methods include the use of an inorganic matrix as a support or host to produce the nanoparticles (28). A silica supported surface containing a silanol group can reduce the chloroaurate ion to AuNPs. The AuNPs generated in this process are bound to the silica surface and catalytically active in the hydrogenation of cyclohexene (28). Supercritical fluid (SCF) technology is also used to prepare lanthanides (Eu, Y, Gd), vanadate, rare earth phosphate, rare earth garnets and other transitional metal based nanoparticles (29). Gadolinium-metal organic framework (GdMOF) nanoparticles can be prepared by reversible attachment-fragmentation chain transfer (RAFT) polymerization (30). The third method, biological synthesis, uses fungus or bacteria as nanofactories (34-35). A number of nanomaterials ( $\mathrm{Au}$ and $\mathrm{Ag}$ ) have been synthesized by this method and are emerging as a green way to produce technologically important nanomaterials $(31,32)$.

\section{Physio-Chemical Properties of Metal Nanoparticles}

The tunablility of optoelectronic properties through shape and size-dependent properties make inorganic nanomaterials unique for various biomedical applications (33-36). Inorganic nanoparticles such as gold, silver and copper possess brilliant colors due to the presence of 
the surface plasmon resonance (SPR) band (39-43). AuNPs show a strong SPR band that is dependent on particle size (37) and dielectric strength of the surrounding medium (38). Gold nanoparticles can also be tuned by surface modifications, such as coating the core with a layer of silica (39). The strong SPR intensity of AuNPs has been used in preclinical models as imaging and therapeutic agents $(37,38)$. Also, this optical absorption and scattering intensity can be tailored by changing the size and shape of the nanoparticle (Fig. 1) (40). The ratio of scattering to absorption increases with increasing size of the particle diameter (20 nm to $80 \mathrm{~nm}) ; 20 \mathrm{~nm}$ nanospheres show only SPR induced absorption with insignificant scattering (41). The deep red color of $20 \mathrm{~nm}$ gold nanoshells have a strong ultra violet visible extinction band at a wavelength of $520 \mathrm{~nm}$, which undergoes bathochromic shift with increasing nanoparticle diameter (41). Stober et al., reported that the optical behavior of gold nanoparticles can be adjusted to the near infrared (NIR) region by synthesizing silica-gold nanoshells and changing the relative core and shell thickness (42-44). This phenomenon was also illustrated with nanorods; SPR can be shifted to NIR by increasing the nanorod aspect ratio $(37,44,45)$.

Chemical and biochemical properties of AuNPs arise from the strong binding affinity of gold with thiols, disulfides, phosphine, and amines (46-48). The strong affinity of gold towards thiol and amine functionalities (according to the SHAB principle) allows many different biological ligands such as DNA, peptides, proteins, antibodies, viruses and receptors to coat the gold surface $(49,50)$. Thus, gold conjugates possess potential applications in various biomedical applications.

Recently super paramagnetic iron oxide nanoparticles (SPION) and gadolinium chelates are gaining interest as MRI agents. SPION are of particular interest due to their sensitivity, biodegradable nature and metabolic pathways of cellular iron (51). Gadolinium (Gd) conjugated $\mathrm{TiO}_{2}$-DNA oligonucleotide nanoparticles also showed increased detection sensitivity when utilized as MRI contrast agents (52). After 48 hours of treatment with Gd$\mathrm{TiO}_{2}$-DNA oligonucleotide nanoparticles, the Gd concentration was 1000 fold higher in cells as compared to the free contrast agent (52).

Other nanomaterials that are gaining momentum as MRI contrast agents are lanthanide based nanomaterials (32) and semiconductor nanomaterials ( $\mathrm{CdS}, \mathrm{CdTe}, \mathrm{CdSe}$ and $\mathrm{ZnS}$ ) due to their strong and stable photoluminescence properties (53). Several dextran coated magnetic nanoparticles (MNPs) are also gaining clinical importance as MRI contrast materials, such as ferumoxides and ferumoxtran; approved by the FDA for detecting solid tumors (54,55). MNPs (Fig. 2) have been used to identify lymph node metastases in solid tumors, imaging angiogenesis, macrophage specific inflammatory pathologies, artherosclerosis, rheumatoid arthritis and neurodegeneration both in vitro and in vivo (5457).

\section{Biological Properties of Gold Nanoparticle}

Nanoparticles and intracellular organelles can be similar in size, depending on the size of the nanoparticle. This raises the possibilities to deliver nanoparticles in an organelle specific manner and extract the intracellular information (58-59). This information could be helpful for the detection, diagnosis and treatment of diseases (60).

As mentioned before, most of the biological applications of gold nanoparticles use it as a passive agent, either as a probe for electron microscopy or as a vehicle to deliver biomolecules into cells. Recently Bhattacharya et al., demonstrated that gold nanoparticles can be used as active agents to interfere directly with the cellular processes and possess antiangiogenic and anti-tumor properties (14). Gold nanoparticles can also be fabricated as a multifunctional nanoplatform for various biomedical applications such as detection and 
diagnosis (61-66). Sokolov et al., has utilized the multifunctional platform of AuNPs by conjugating an antibody to bind to epidermal growth factor receptors (EGFR). This receptor is overexpressed in cervical cancer cells. Therefore treatment with these Au conjugates enhances detection of cervical cancer cells due to the enhanced SPR scattering of the AuNPs by laser scanning confocal reflectance (Fig. 3) (62,67). To test the specificity of the aforementioned AuNPs, bovine serum albumin (BSA) was conjugated to AuNPs and tested with cervical cancer cells, this assay did not exhibit any SPR scattering confirming the specificity of the antibody-conjugated gold particles (62). Toxicity and biodistribution of AuNPs and various other nanoparticles has been studied in vitro and in vivo $(68,69)$. Similarly, anti-EGFR antibodies conjugated to gold nanorods have been used with NIR scattering to selectively administer photothermal damage to the targeted cancer cells (7071). Rotello and his co-workers have reported that ligand modified AuNPs can interact with $\alpha$-chymotrypsin resulting in enzyme inhibition, followed by enzyme denaturation (72). Upon interaction with cellular millue, certain nanoparticles generate a coating of protein around the surface; the protein "corona" (71). Research is ongoing to understand the AuNP-protein dynamics and identify the proteins involved in the corona around AuNPs. Such understanding may lead to the identification of new biomarkers not only for cancer but for other diseases.

\section{Au-nanoparticles as a Delivery Shuttle}

Nanoparticles can be used for site specific delivery of cytotoxic drugs with the potential to minimize toxicity and reduce harmful side effects. In this section, we will discuss the fabrication of a gold nanoparticle-based targeted drug delivery system (TDDS) (Fig. 4)(73).

Anti-EGFR antibody cetuximab (C225) has been approved by the FDA for the treatment of EGFR-positive colorectal cancer. It is also in different phases of clinical trials for many other malignancies $(74,75)$. Recently our group demonstrated that targeted delivery of a low dose of gemcitabine using cetuximab as a targeting agent and gold nanoparticles as a delivery vehicle resulted in significant inhibition of tumor growth in an orthotopic model of pancreatic cancer (Fig. 4A) (76).

Other targets include folate receptors (FRs). FRs are overexpressed in various cancers such as breast, ovary, brain and kidney $(77,78)$. These FR-positive cancers can be targeted using folic acid (FA) or anti-folate as a targeting agent. Folic acid serves as a regulatory component of cell growth, genetic replication and a building block of proteins in cells. The FR expression is amplified two fold or even higher upon the advancement of cancer stage/ grade $(2,79,80)$. FR is expressed selectively on the membrane surface of normal polarized epithelial cells and thus shielded from FR-directed therapeutics delivered in plasma. When cell polarity is lost upon epithelial cell transformation, FRs become accessible for targeted drugs in blood circulation (81). FR expression is not harmful, rather required by healthy tissues (82). Recently, gold nanoconjugates were synthesized to target the FR on various cancer cells (Fig. 5). Polyethylene glycol (PEG) was used as a linker between folic acid and relevant drug molecules. The usage of PEGylated molecules was helpful to achieve quick renal clearance of non-targeted conjugates thereby minimizing the toxic effects towards normal cells. Another advantage to conjugating PEGylated molecules to AuNPs is stabilization during blood circulation, minimal degradation, and nonimmunogenicity. Andres et al., has shown TEM analysis of cellular uptake for FA coated AuNPs with KB cells and WI-38 cells (83). KB cells are (human carcinoma of nasopharynx) human cancer cells that overexpress FR. WI-38 cells are (normal human fetal lung fibroblast) human cells that have poor expression of FR. It is clearly depicted in this analysis that the FA coated AuNPs are present in KB cells but not apparent in WI-38 cells. 
Other examples of AuNP based drug delivery systems are AuriTax and Aurimune-T. AuriTax and Aurimune-T are both multivalent systems assembled on $25 \mathrm{~nm}$ AuNPs. AuriTax is composed of tumor necrosis factor (TNF), paclitaxel and PEG. Aurimune-T merely contains TNF and PEG. Animal studies revealed that Aurimune-T had a 10 fold increase in efficiency in vivo compare to TNF alone (2,3). Numerous other nanoparticles such as magnetic (54), lanthanide $(30,52,84)$, anionic clay, silver $(85,86)$, and many polymer based particles $(87,88)$ are gaining interest as drug delivery platforms. Accumulating evidence indicates that multi-functional engineered nanoparticles can enhance the therapeutic delivery and overcome multi-drug resistance (MDR) through multivalency and the incorporation of a resistance modulator (89).

\section{Nanoparticles as Therapeutics}

Due to their unique physicochemical and optoelectronic properties, inorganic nanomaterials can also be considered as a therapeutic molecule. This idea is relatively new and several laboratories are working on exploring the therapeutic application of inorganic nanomaterials. In this section we will discuss some of the recent examples of therapeutic inorganic nanoparticles. A list of nanoparticle based drugs that are promising candidates for therapeutics, are summarized in Table 1.

\section{A. Naked AuNP as an Anti-Angiogenic Agent}

One of the key factors in the growth and spread of tumor cells is angiogenesis. This is the process of new blood vessel and capillary formation from preexisting ones $(90,91)$. Blood vessels supply oxygen and other nutrients to tumor cells, allowing them to grow, migrate, and metastasize to different organs. Tumor angiogenesis is predominantly triggered by endothelial specific mitogens, such as vascular endothelial growth factor (VEGF), basic fibroblast growth factor (bFGF), platelet derived growth factor (PDGF), and transforming growth factor-beta (TGF- $\beta$ ) (92-94). Unlike normal blood vessels, tumor blood vessels are leaky in nature, highly permeable to plasma and heterogeneous, both structurally and functionally (95). In 1971, Dr. Judah Folkman proposed the idea of angiogenesis and its role in tumor growth $(96,97)$. He pioneered the idea of treating cancer with anti-angiogenic agents (94-97). There are numerous anti-angiogenic molecules in various phases of clinical trials; many of them have been approved as cancer therapeutics (98). Unfortunately, some of these agents have shown signs of toxicity $(99,100)$.

Recently, our group has reported that gold nanoparticles inhibit VPF/VEGF-165 mediated endothelial cell proliferation both, in vitro and reduced ascites accumulation in vivo (14). These AuNPs were shown to bind the heparin binding domain and actively inhibit heparin binding growth factors such as VEGF-165 and bFGF. However, these AuNPs did not inhibit the function of non-heparin binding growth factors such as VEGF-121 and epidermal growth factor (EGF). In vitro, phosphorylation, intracellular calcium release, and RhoA activation were substantially reduced through AuNP inhibition of the VEGF165 (14). In vivo, AuNPs were administered to a male mouse ear that was pretreated with adenovirus producing mouse VEGF. The results of the AuNP treatment demonstrated the reduction of angiogenesis and edema formation (Fig. 6). AuNPs have also been shown to inhibit the proliferation of multiple myeloma cells (101). Multiple myeloma (MM) is a plasma cell disorder $(102,103)$. Many growth factors (VEGF, insulin like growth factor-I (IGF-I) and TNF- $\alpha$ ) were reported to be responsible for multiple myeloma cell growth and proliferation. Therapies for multiple myeloma include the coupling of chemotherapeutics with or without stem cell transplantation, alkylating agents, thalidomide, and proteasome inhibitors (104). Naked AuNPs have also been utilized in the study of treatments for MM (107). They were shown to cause cell cycle arrest in the G-1 phase followed by up regulation of p21 and p27, thus inhibiting cell proliferation (101). In other studies, gold conjugated with anti-VEGF 
antibody (AbVF) induced dose dependent apoptosis as compared to AuNP or AbVF alone for the treatment of B-chronic lymphocytic leukemia (CLL-B) $(101,105)$.

\section{B. Photothermal Therapy (Hyperthermia) for Cancer Treatment}

Treatment options for cancer are dependent on the type and stage of the cancer (106-109). All anti-cancer therapies have limitations due to toxic side effects arising from non-specific drug delivery, poor bioavailability, short half-life and radiation damage to healthy cells. Photothermal therapy is a viable approach; several heat sources (microwaves, ultrasound, radiofrequency and lasers) have been tested for cancer treatment, unfortunately they damage surrounding cells by non-specific heating (116-118).

Hyperthermia, by definition is the application of heat to kill tumor cells with a temperature above $40{ }^{\circ} \mathrm{C}$. It has been used alone and in combination with chemotherapy and radiation therapy $(110,111)$. Higher temperatures (above $42{ }^{\circ} \mathrm{C}$ ) cause necrosis of the live cell, denature enzymes $(112,113)$, promote functional changes to DNA and RNA (113), rupture the cellular membrane releasing cellular content, ultimately leading to cell injury and death $(114,115)$. However, the undifferentiated heating of both normal and malignant cells is a major concern and thus requires a rational design for targeted and regulated delivery. Gold nanoparticles can be used as a probe for hyperthermia due to their unique physicochemical properties.

The strong SPR absorption of Au nanoparticles can be converted from absorbed light to heat within picoseconds ( 1ps) $(37,44,45,116)$. El-Sayed et al., was able to target EGFR positive human (oral) squamous carcinoma cells (HSC and HOC) with AuNPs conjugated with EGFR antibodies. After AuNP treatment the cells were excited with an argon-ion laser at $514 \mathrm{~nm}$, this converted the SPR band of the AuNPs to heat (117) and resulted in death of the cells. To determine the extent of photothermal damage, the cells were stained with trypan blue. Dead cells appeared blue (Fig. 7) whereas the live cells remained unstained $(118,119)$. Malignant cells showed photothermal damage with $25 \mathrm{~W} / \mathrm{cm}^{2}$, interestingly it took $50 \mathrm{~W} / \mathrm{cm}^{2}$ to cause damage to healthy cells (117).

Silica coated $\mathrm{Fe}_{3} \mathrm{O}_{4}$ magnetic nanoparticles (MNP) are also used in hyperthermia treatment $(120,121)$. A large amount of heat can be generated from MNPs due to loss of energy produced by the magnetic hysteresis loop (122). The extent of heat created can be tuned by the magnetic field parameter and formulation of the metal surface (123). A recent study shows that lanthanum magnetite particles with silver doping are ideal materials for hyperthermia $\left(\mathrm{T}_{\mathrm{C}} 41-44{ }^{\circ} \mathrm{C}\right)(86)$. These nanoparticles show stability in living tissue, and elicit brilliant colors in mice brains when used as a MRI agent. Another use of MNPs was demonstrated with the administration of magnetic cationic liposomes in combination with TNF- $\alpha$ and stress inducible promoters resulting in significant tumor inhibition (124). MNPs have also showed selective uptake by tumors when attached with tumor specific antigens during hyperthermia therapy (125).

Nanoparticle mediated hyperthermia in vivo requires deeper energy penetration through skin and tissue. Recently, core-shell nanomaterials have been used as a probe for hyperthermia using near infrared (NIR) (135). Gold nanorods with silica coating exhibit NIR scattering. The core and shell thicknesses can be tuned to change the optical properties of the nanoparticles resulting in a shift from visible to the NIR region. Hirsch et al., reported the use of NIR with silica-gold nanoshell for photothermal therapy of human breast cancer cells in vitro and in vivo (126). An in vivo study utilizing NIR exposure for 4-6 minutes indicated irreversible tissue damage and generated a temperature of $37.4 \pm 6.6^{\circ} \mathrm{C}(126)$, as evident from MRI data. El-Sayed et al., also reported that gold nanorods could be used as a contrast agent for both molecular imaging and selective photothermal therapy with the use of NIR 
irradiation. They also demonstrated that NIR irradiation of gold nanorods conjugated with anti-EGFR antibodies showed a clear distinction between healthy (HaCaT) and cancerous cells (HOC-313 \& HSC-3) (Fig. 8) (70). Cells were treated with these nanoconjugates and subsequently exposed to Ti: sapphire laser $\left(800 \mathrm{~nm}, 40-160 \mathrm{~W} / \mathrm{cm}^{2}\right)$, malignant cells showed evidence of damage at half the energy required to damage healthy cells (74).

Griffin et al., extrapolated on this idea and reported the use of PT-cAu-TNF- $\alpha$ (PT signifies thiol derivatized polyethylene glycol) for targeted delivery of TNF- $\alpha$ and hyperthermia to illustrate destruction of SCK murine mammary carcinoma. Contrast enhanced Doppler ultrasound was utilized as a visualization technique to determine SCK tumor perfusion defects. Treatments were performed for 1 and 5 days, and the treatments tested PT-cAuTNF- $\alpha$, PT-cAu, and TNF- $\alpha$ in various concentrations, both with heat and without (127). The least amount of cell survival and persistent perfusion was achieved with PT-cAu-TNF- $\alpha$ and heat, resulting in a mere $21 \%$ of the control (136). A comparative study of antibody coated Au-based nanomaterials (silica coated Au nanoshells, hollow Au/Ag nanospheres and Au nanorods) administered in HeLa (cervix cancer), TCC (bladder cancer) and A549 (lung cancer) cells revealed photodestructive efficiency of each nanomaterial. The antibody coating allowed for penetration of the cells and NIR was used at $808 \mathrm{~nm}$ to heat the cells and promote destruction. The efficacy was determined by the number of particles required to cause cell death with fixed laser energy. These experiments revealed that minimum silica coated Au nanoshells were needed to produce efficient photodestruction, consequently the Au nanorods required the largest number of particles to produce similar cell destruction (128).

Photocatalyzed titanium dioxide $\left(\mathrm{TiO}_{2}\right)$ nanoparticles possess antitumor properties (129). Due to the logistical limitations of introducing UV light in situ the employment of $\mathrm{TiO}_{2}$ particles for human therapy is restricted. However, $\mathrm{TiO}_{2}$ particles are still of interest from a nonphotocatalyzed anti-cancer perspective. Functionalizing the surface of $\mathrm{TiO}_{2}$ with alcohol, amine and carboxylic acid groups were studied in vitro and in vivo for evaluation of non-photolytic antitumor properties. Lung carcinoma, JHU (prostrate cancer), 3T3 fibroblasts, and B16F10 melanoma were all treated with alcohol, amine and carboxylic acid functionalized $\mathrm{TiO}_{2}$ nanoparticles. Results revealed membrane disruption by these nanoparticles caused cell death. However, amine and alcohol functionalized particles rendered higher toxicity than carboxylic functionalized particles; cell viability was seen to be dependent on particle concentration, cell types and the surface chemistry of the particle (129).

\section{Inorganic Compounds for Photoactivated Chemotherapy (PACT)}

Transition metals are a growing area of interest for inorganic nanoparticle based cancer therapeutics (130). Upon photoexcitation, these metals can radiate the excited energy by releasing electrons (photochemically or photophysically), loosing ligands and transferring energy (electrons) to nearby species. Photoactivated chemotherapy for d-block metals such as Ti, V, Cr, Mn, Re, Fe, Ru, Os, Co, Rh, Ir, Au, $\mathrm{Pt}$ and $\mathrm{Cu}$ have potential for greater exploration (130). The photophysics of $\mathrm{Ti}, \mathrm{V}, \mathrm{Fe}, \mathrm{Cu}, \mathrm{Rh}, \mathrm{Pt}$ and $\mathrm{Au}$ have been well studied and demonstrated anticancer activity.

Transition metals can be easily excited with visible and UVA light, leading to various electronic and vibrational states where orbitals may possess mixed metal/ligand character depending on the class of the metal-ligand bond. Once electrons reach the photoexcited state several possible photophysical phenomena occur to achieve the ground state electronic structure (intersystem crossing (ISC), internal conversion (IC), vibrational relaxation and solvation dynamics) (130). The lifetime of this metal ion electronic transition is short (50 
ns-1 $\mu$ s) compared to organic compounds and the quantum yield is quite high for this photo transition. Transition metal complexes having $\mathrm{d}^{3}$ and $\mathrm{d}^{6}$ electronic configurations show remarkable photophysical properties. There are different types of electronic transitions; metal-metal (d-d), ligand field (LF), charge transfer (CT) and ligand centered (LC). Metal centered transitions are mainly orbital forbidden and occasionally spin forbidden resulting in weak absorption intensities. Metal centered transitions mostly reside in the antibonding orbitals; thus photochemical lability favors the release of the ligand (bioactive $\mathrm{NO}, \mathrm{CO}$ ) and ligand substitution (131). Charge transfer complexes are defined as involving metal to ligand (MLCT), metal to solvent (TS) or ligand to metal (LMCT) transitions and have intense molar absorptivity. They can trigger redox reactions resulting in free radicals capable of DNA damage under physiological conditions. Photoexcited states of metal complexes such as triplet states de-energize by transferring energy to the ground state triplet oxygen, generating highly reactive singlet oxygen $\left({ }^{1} \mathrm{O}_{2}\right)$. The energy of the triplet excited state metal complex must be $>-94 \mathrm{~kJ} \mathrm{~mol}^{-1}$ in order for this photophysical phenomenon to occur $(130,132)$. The excited singlet oxygen has the potential to damage DNA, modify the protein, promote lipid peroxidation and destroy the tumor microenvironment (133). This process is known as photodynamic therapy (PDT) where the quantum yield of singlet oxygen generation is an imperative parameter; $\mathrm{d}^{0}\left(\mathrm{Mg}^{\mathrm{II}}, \mathrm{Al}^{\mathrm{III}}\right)$ or $\mathrm{d}^{10}\left(\mathrm{Zn}^{\mathrm{II}}, \mathrm{Cd}^{\mathrm{II}}\right)$ configurations have modest to high values of quantum yield $(130,132)$. The photoexcited energy can be liberated as heat instead of radioactive decay, and this can damage the cancer cells. Optimum wavelength for phototherapy requires $620-850 \mathrm{~nm}$ to achieve maximum tissue penetration. Group 3 compounds Sc, Y and La (mostly in +3 oxidation state) have strong photoluminescence properties which heightens their appeal as contrast agents, however group 3 elements have yet to be explored for PACT. Group 4 elements such as Ti, specifically as $\mathrm{TiO}_{2}$, have the capability to destroy cancer cells. Irradiation of $\mathrm{Ti}^{4}$ with UVA light stimulates photoreduction to $\mathrm{Ti}^{+3}$ generating free radicals which ultimately damage cancer cells (134). Group 5 compounds, such as vanadium (IV) complexes have been shown to cleave DNA through a photochemical mechanism $(134,135)$. Group 6 compounds $\mathrm{Cr}$, Mo and $\mathrm{W}$, especially porphyrin complexes with Mo show excellent photochemical properties, but their role for PACT has not been characterized. Chromium ${ }^{\mathrm{III}}$ diimine complexes such as $\left[\mathrm{Cr}(\mathrm{phen}) \mathrm{Cl}_{2}\right]$ are capable to bind DNA and can photorelease a coordinated axial ligand $(\mathrm{Cl})$ (136). Group 7 complexes, Mn ${ }^{\mathrm{III}}$ porphyrins have potential for PDT. Re and Tc (radioisotopes) are mainly used for imaging and radiotherapy $(137,138)$. Group 8 compounds have a rich background in the use as photosensitizers and DNA intercalators. They are capable of releasing bioactive molecules photophysically. Iron (III) triazine complex can cleave plasmid DNA by producing ROS upon irradiation $\left(72 \mathrm{~h}, \lambda_{\text {irr }}>455 \mathrm{~nm}\right)$ in a LMCT excitation (139). Hydroxyl, superoxide and triazine radicals all can cleave DNA. Ruthenium ${ }^{\mathrm{III}}$ can undergo photoactive reduction to $\mathrm{Ru}^{\mathrm{II}}$, in turn reacting with DNA either photochemically or thermally. Ruthenium complexes can intercalate DNA and form adducts of DNA (140). Osmium also exhibits photochemistry and has been utilized for PACT in a mixed metal system. Synthetic obstacles have made Os only systems difficult, but the low energy MLCT bands continue to make this system attractive. Group 9 complexes, $\mathrm{Co}^{\mathrm{III}}$ and $\mathrm{Rh}^{\mathrm{III}}$ possess anticancer properties based upon experimental conditions and ligands. Cobalt ${ }^{\mathrm{III}}$ complexes such as cis-[CoL $\left.\left(\mathrm{NO}_{2}\right)(\mathrm{ONO})\right]^{+}$releases $\mathrm{NO}$ upon photo activation $\left(\lambda_{\text {irr }}=360 \mathrm{~nm}\right)$ which sensitizes the hypoxic tissue towards $\gamma$-radiation and the thermal release can cleave DNA (141-144). Photoreduction of $\left[\mathrm{Co}^{\mathrm{III}}(\mathrm{en})_{2}(\mathrm{dppz})\right]^{3+}$ photocleaves the DNA backbone $\left(\lambda_{\text {irr }}=350-400 \mathrm{~nm}\right)$, this mechanism quenches the excitation and produces guanine radical cation $\mathrm{G}^{++}(145)$. Barton et al., has reported the use of $\left[\mathrm{Rh}(\text { bpy })_{2} \text { (chrysi) }\right]^{3+}$ to detect DNA mismatching upon photoactivation $\left(\lambda_{\text {irr }}=340-450 \mathrm{~nm}\right)$, thus a potential for PACT. Mismatches in DNA have been reported to be involved in many cancers (146). A few reports have been published on group $\mathbf{1 0}$ metals such as Ni. Photoirradiation of Ni complexes generates ROS which cleaves DNA, but Ni complexes bind to DNA without irradiation (147). Platinum employment for PACT is well documented. Upon irradiation, 
$\mathrm{Pt}^{\mathrm{IV}}$ diazido complexes cause photo dissociation of the ligands due to weaker d-d transitions at $(\lambda \operatorname{irr}=420,514 \mathrm{~nm})$. Also, photoreduction of $\mathrm{Pt}^{\mathrm{IV}}$ to $\mathrm{Pt}^{\mathrm{II}}$ occurs and exhibits acute toxicity in cell cultures, consequently this phenomenon is totally absent in the absence of light $(148,149)$. Palladium compound (TOOKAD) is in phase I/II clinical trials for the treatment of prostate cancer by PDT (150). Group $\mathbf{1 1}$ complexes such as, $\mathrm{Cu}$ complexes have been reported to cleave DNA in a photodependent manner $\left(\lambda_{\text {irr }}=700-755 \mathrm{~nm}, \mathrm{NIR}\right)$ and without direct irradiation. The proposed mechanisms for the DNA damage are, in the presence of $\mathrm{O}_{2}$, a hydroxyl radical and singlet oxygen are generated and under hypoxic conditions a sulfur anionic radical is produced (151). Minimal research has been reported on Ag for the use in PACT, especially in comparison to the extensive studies that have been performed using Au. Group 12 complexes, such as Zn-porphyrins are used for PDT, but the most promising group 12 element is Cd $(152,153)$. Cd based quantum dots (QD) have the potential to generate the ROS which can kill cancer cells. Cd QDs can be tracked through imaging and used as a PDT agent once irradiated with X-rays $(154,155)$.

\section{Use of Radioisotopes of Colloidal Gold}

Radioactive isotope ${ }^{198} \mathrm{Au}$ disintegrates to a beta particle of $0.98 \mathrm{MeV}$ and emits two gamma radiation $(0.12$ and $0.41 \mathrm{MeV})$ with minimal tissue penetration $\left(0.38 \mathrm{~mm}, \mathrm{t}_{1 / 2}=2.7\right.$ days) (156). The lower permeability of ${ }^{198} \mathrm{Au}$ makes it capable of delivering a high amount of ionizing radiation to a localized tumor area without affecting the normal tissue (157). Another advantage of using ${ }^{198} \mathrm{Au}$ is its short half-life and it does not require removal of the radio source (157). The use of radiogold is very efficient; it has a $96.3 \%$ patient survival rate for the treatment of stage Ia ovarian cancer $(158,159)$. Radiogold has also been used in the treatment of hepatic carcinoma and endometrial cancer with minimal side effects compared to traditional radiotherapy (7). Despite these successes the therapeutic efficacy achieved by radiogold is limited (160).

Radioactive gold has been applied in the treatment for several tumors (prostate cancer, bronchogenic carcinoma, nasopharyngeal carcinoma, head and neck cancer) (7). Chanda et al., has administered radioactive gold conjugated with gum arabic glycoprotein (GA) in a human prostrate tumor xenografts of SCID (severely compromised immunodeficient) mice (161). Intratumoral administration of beta-emitting radiogold inhibited tumor growth without showing any obvious side effects. Tumor volumes were reduced to $82 \%$ compared to the control and pharmacokinetics revealed the accumulation of GA- ${ }^{198}$ AuNPs inside the tumor region with minimal leakage of radioactivity to untargeted organs (161). Blood component analysis showed similar results to normal SCID mice, implying therapeutic efficacy and non-toxic behavior of radiogold in vivo. A study by Parmerswaran et al. has reported the use of gold nanoshells for in vivo tumor radiation therapy and reduction of the hypoxic fraction of tumors as well as the vascular disruption of malignant tissue. This result indicates the antihypoxic and noninvasive nature of gold nanoshells, thus useful for combining with other tumor ablation therapies (162).

Platinum nanoparticles have been applied for radiation with fast ions, employed for hadron therapy (163). Applying this strategy, Pt nanoparticles enhanced double strand DNA cleavage (DSBs) by a factor of 2 . The use of high- $\mathrm{Z}$ atoms embedded in compounds can potentiate the effect of ionizing radiation, due to the electronic transmission in the neighboring high- $\mathrm{Z}$ atom (164). The presence of a high ionizing cross section and the augur de-excitation processes, results in amplification of ionization density and in turn, the dose (165). Platinum nanoparticles with polyacrylic capping were prepared by radiolytic reduction of platinum complex, $\left(\mathrm{Pt}\left(\mathrm{NH}_{3}\right)_{4} \mathrm{Cl}_{2} \cdot \mathrm{H}_{2} \mathrm{O}\right)(163)$. The proposed mechanism involved the generation of hydroxyl radicals catalyzed by radioactivated Pt particles and 
subsequently the cleavage of DSBs (Fig 9). Novel approaches of hadron therapy using Pt nanoparticles direct a new method for cancer therapy.

\section{Inorganic Nanoparticles as a Carrier for Photodynamic Therapy (PDT)}

Photodynamic therapy (PDT) is getting attention as an alternative treatment for cancer. The principles of PDT requires using a photosensitizer that becomes excited upon irradiation then the energy is transferred to the surrounding oxygen to generate a highly reactive oxygen species (ROS), such as singlet oxygen $\left({ }^{1} \mathrm{O}_{2}\right)$. This singlet oxygen can oxidatively modify the neighboring lipids, proteins, amino acids and nucleic acid content of the cellular component and thereby lead to cellular damage by necrosis, and/or apoptosis (166). An example of a FDA approved photosensitizer is Zinc (II) phthalocyanine; a highly specific antitumor agent demonstrating cytotoxicity both in vitro and in vivo (163). The use of nanoparticles as a delivery vehicle for hydrophobic and insoluble photosensitizing drugs could remarkably progress the application of PDT. Also, the issue of tissue penetration of light could be overcome by using fluorescent nanoparticles doped with photosensitizing drugs, which are tunable from the NIR region to the visible. The Zhang group has reported the use of sodium yttrium fluoride nanocrystals with a mesoporous silica coating to enhance the uptake of $\mathrm{ZnPc}$ to murine bladder cancer cells (MB49) in a concentration dependent fashion at $980 \mathrm{~nm}(84,167,168)$. Silica encapsulation aides in the light activation while also protecting against degradation in a bioenvironment, and allowing for better contact with the oxygen, in turn increasing the release of sodium yttrium fluoride nanoparticles. Cytotoxicity in MB49 cells due to the photodynamic effect of nanoparticles was explored through cell viability, confocal microscopy and DNA agarose gel experiments. This study illustrates the potential of using sodium yttrium fluoride as an agent for photodynamic therapy. Roy et al., has demonstrated the use of ceramic nanoparticles to deliver hydrophobic photosensitive anti-tumor agents. The drug trapped in nanoparticles showed higher fluorescence compared to the free form. In vitro analysis indicated greater cellular uptake and upon irradiation, more singlet oxygen was produced and in turn more damage to the tumor cells was achieved (169).

Inorganic oxide-, metallic-, ceramic- and biodegradable polymer based nanoparticles are getting attention as efficient carriers for photosensitizing drugs (170). Lai et al., reported $\mathrm{Fe}_{3} \mathrm{O}_{4}$ functionalized with an iridium-complex and $\mathrm{SiO}_{2}$ served as an effective combination for photosensitizing and phosphorescent probe for imaging and therapeutics (171). HeLa cells were treated with this multifunctional nanohybrid and the uptake of nanoparticles into the cells was confirmed by MRI. Photodynamic therapy induced cellular damage and the loss of organelles, as apparent for ${ }^{1} \mathrm{O}_{2}$ mediated apoptosis $(170,171)$. The drawback of the design was the requirement of $366 \mathrm{~nm}$ radiation, which is not very efficient for tissue penetration. Employing porphyrins as photosensitizers can be achieved through attachment to various doped nanoparticles $\left(\mathrm{CaF}_{2}: \mathrm{Eu}^{2+}, \mathrm{BaFBr}^{2} \mathrm{Eu}^{2+}, \mathrm{BaFBr}: \mathrm{Mn}^{2+} \mathrm{CaPO}_{4}: \mathrm{Mn}^{+2}\right.$, $\mathrm{LaF}_{3}: \mathrm{Ce}^{+3}$ and $\left.\mathrm{LuF}_{3}: \mathrm{Ce}^{+3}\right)$ and semiconductor nanoparticles $\left(\mathrm{ZnO}, \mathrm{ZnS}\right.$ and $\left.\mathrm{TiO}_{2}\right)$ (172).

\section{Nanoparticles as Antioxidants}

Oxidative stress and ROS generation is recognized to play a critical role in a wide range of diseases, including cancers (173). Yin et al., has shown that $\left[\mathrm{Gd} @ \mathrm{C}_{82}(\mathrm{OH})_{22}\right]_{\mathrm{n}}$ (endohedral metallofullernol) nanoparticles decreased the ROS generation and induced the production of phase II enzymes associated with destruction and metabolism of ROS species, in vivo (174). An in vitro study using liposomes from bovine liver phosphatidylcholine showed that $\left[\mathrm{Gd} @ \mathrm{C}_{82}(\mathrm{OH})_{22}\right]_{\mathrm{n}}$ nanoparticles can eliminate ROS as well as inhibit lipid peroxidation. In vitro and in vivo studies using human lung adenocarcinoma cells clearly indicated the reduction of ROS formation, decrease of mitochondrial damage and inhibition of malignant 
tumors (174). This data raises the possibility of $\left[\mathrm{Gd} @ \mathrm{C}_{82}(\mathrm{OH})_{22}\right]_{n}$ nanoparticles mediating tumor inhibition through the antioxidant ability of the nanoparticles. Recent studies indicate that rare earth cerium oxide $\left(\mathrm{CeO}_{2}\right)$ nanoparticles can act as a radical scavenger and prevent healthy tissue from radiation-induced damage (175-177). Thus $\mathrm{CeO}_{2}$ nanoparticles could serve as regenerative medicine for normal tissue. Animal studies revealed $\mathrm{CeO}_{2}$ nanoparticles were well tolerated by cells and protected against radiation induced pneumonitis (175). This study suggests a new approach to using nanotechnology for preserving human health receiving radiation therapy.

\section{Other Inorganic Nanoparticles for Cancer Therapy}

Silver also has an extensive historical background for medical use $(178,179)$. J. N. Burst first used silver treatment during World War II for burn victims (180). Silver nanoparticles have been well accepted and shown great success as a biocide against microbial infections, burns and diabetic skin ulcers (178). The biological activity of silver has been attributed to the presence of the $\mathrm{Ag}^{+}$ion. Two examples of medicinal silver based compounds being used clinically are silver sulfadiazine and actisorb silver $220(178,181)$. The anti-microbial activity of silver stems from the positively charged ion actively binding with negatively charged proteins, RNA and DNA to inhibit cell replication. Silver nanoparticles (1-10 nm) bind to HIV-1 and drastically inhibited the HIV infection compare to a BSA (Bovine Serum Albumin) surface modified silver particle (182). Recently, Qingzhi et al., reported that glutathione assisted preparation of silver nanoparticles passivated with BSA possess tunable optical features dependant on size and surface coverage, which is potentially relevant for biomedical applications (85).

Medicinal use of platinum nanoparticles is not well known, rather platinum compounds are more popular as anti-tumor agents (cis-platin and its derivatives) (183). Platinum nanoparticles have been used recently for medicinal purposes, mostly as a composite of other nanoparticles in the form of core-shell. Yolk-shell nanoparticles $\left(\mathrm{FePt} @ \mathrm{CoS}_{2}\right)$ showed more efficient killing of HeLa cells $\left(\mathrm{IC}_{50}=35.5 \pm 4.7 \mathrm{ng} \mathrm{Pt} / \mathrm{ml}\right)$ compare to cis-platin $\left(\mathrm{IC}_{50}\right.$ $=230 \mathrm{ng} \mathrm{Pt} / \mathrm{ml}$ ) (184). This structurally modified platinum nanoparticle could be very useful to minimize the cytotoxicity of drugs. Platinum nanoparticles were also used in combination with multi walled carbon nanotubes (MWCNTs) to enhance the sensitivity of electrochemical biosensors and the catalytic efficiency of platinum nanoparticles. The catalytic sensitivity of the detection for DNA was enhanced to $1.0 \times 10^{-11} \mathrm{~mol}^{-1}$ (171). Recent reports confirm that face centered cubic (fcc) FePt nanoparticles conjugated with LHRH (luteinizing hormone-releasing peptide) via phospholipids can inhibit tumor growth (for human ovarian cancer (OVA2780) that overexpresses the LHRH) in a pH dependent (low $\mathrm{pH} \sim 4.8$ ) manner (185). The mechanism of action involves the generation of a hydroxyl radical ( $\mathrm{HO}$ ), via catalytic decomposition of $\mathrm{H}_{2} \mathrm{O}_{2}$ by $\mathrm{Fe}^{+2}$. Thus, fcc-FePt NPs offer a new platform for nano fabrication with peptides, lipids and antibodies for targeted drug delivery and could also be used for MRI due to their contrast enhancing properties. $\mathrm{Xu}$ et al., has used the dumbbell shaped $\mathrm{Au}-\mathrm{Fe}_{3} \mathrm{O}_{4} \mathrm{NPs}$ to accommodate platinum based anticancer drugs with herceptin antibody and used the NP scaffold for targeted delivery of platin compounds to breast cancer cells (SK-BR-3) (186). Dhar et al., has also demonstrated the in situ release of the cytotoxic drug cisplatin after intracellular reduction of prodrugs. They have specifically targeted prostate cancer cells by using a functionalized Pt (IV) prodrug encapsulated with prostate specific membrane antigen (PSMA) with a PEG modified polyglycolic acid (PLGA) (88). The Lin group has reported the nano scale preparation of coordination polymer (NCP) as a multidentate bridging ligand and demonstrated the controlled release of platinum anticancer drugs to HT-29 cells (angiogenic human colon carcinoma cell) (87). Cell viability assays and dose response curves revealed the systematic dissolution of the NCP coated Pt-drugs at the tumor site. 
Other nanoparticles include the use of metal oxides such as $\mathrm{SiO}_{2}$ with functionalized surfaces and $\mathrm{Fe}_{3} \mathrm{O}_{4}$ (magnetic nanoparticles) as a vector for targeted delivery of drugs and genes with reasonably low toxicity (187). These nanoparticles can be easily synthesized and well characterized in the lab. Wider et al., has used magnetic nanoparticles for drug delivery of doxorubicin into sarcoma tumors of rat model regulated by a magnetic field (188).

Magnetic nanoparticles with a PEG modified surface showed appreciable increase in cellular uptake by breast cancer cells (BT20) compared to unmodified particles (189). Recent reports show calcium phosphate and magnesium phosphate nanoparticles (30-40 nm diameters) are great transfection agents for DNA. The transfection efficiency to HeLa cells showed comparable results to the commercial agent Polyfect (190). Calcium-magnesium phosphate nanocomposits were reported to be better transfection agents and subsequently triggered higher expression of genes (10 times) than individual transfection agents (191).

The use of boron and gadolinium nanoparticles is well known for treating cancer cells with neutron capture therapy (NCT). Inorganic $\mathrm{Gd}(\mathrm{OH})_{3}$ nanoparticles showed an increase in potency compare to organic $\mathrm{Gd}$ emulsions (29). The accumulation of tumor tissue increased 25 times when $30 \mathrm{~nm} \mathrm{Gd}(\mathrm{OH})_{3}$ nanoparticles (instead of $100 \mathrm{~nm}$ ) were applied to tumor bearing hamsters (32).

Other inorganic nanoparticles such as $\mathrm{ZnS}, \mathrm{CdS}, \mathrm{CdTe}$, and $\mathrm{PbS}$ are also known as quantum dots (QD) and possess bright luminescent properties (192). The fluorescence emission of most quantum dots is adjustable according to size and chemical composition. They are very useful tools as biodiagonistic probes for imaging. Proteins and peptides can also be attached to QDs for site-specific delivery to target organs.

Several other metal nanocomposits can be synthesized from layered double hydroxides (LDHs) or clay compounds of different metals ( $\mathrm{Mg}, \mathrm{Zn}, \mathrm{Ca}, \mathrm{Co}, \mathrm{Fe}, \mathrm{Ni}, \mathrm{Cu}, \mathrm{Al}, \mathrm{Fe}, \mathrm{Cr}$ and $\mathrm{Ga}$ ) with varying composition, synthetic preparation and size (30-100 nm hydrodynamic radius) (187). Many other lanthanides such as gadolinium nanoparticles can be used as a magnetic contrast agent for MRI imaging (202). Oyewumi et al., reported that folate, PEG and thiamine modified gadolinium nanoparticles can be easily taken up by the tumor cells (193). Targeted delivery of gadolinium nanoparticles to the tumor could enhance the efficiency of tumor damage by neutron capture therapy, due to its large emission of photons with long flight range. These studies show that the properties (size, shape, optical and chemical) of many periodic table metals can be utilized to prepare a wide range of nanomaterials for applications in cancer therapy.

\section{Toxicity of Inorganic Nanoparticles}

Existing preclinical data shows that gold nanoparticles are relatively non-toxic (194). The favorable toxicity profile of gold nanoparticles makes it attractive for various medical applications, such as wires in pacemakers, intravenous contrast for imaging, real time pregnancy detection and noninvasive detection of lung cancer $(2,5,60,160)$. No biochemical or hematological toxicities were observed when a high dose of $1.9 \mathrm{~nm}$ AuNPs $(2.7 \mathrm{~g} \mathrm{Au} / \mathrm{kg}$ ) were injected into the tail vein of mice (160). Studies are ongoing to determine the immune response of various base nanoparticles and their conjugates.

A study of the toxicity effects of starch coated silver nanoparticles with human glioblastoma cells (U2510) and human lung fibroblast cells (IMR-90) revealed that AgNPs caused ATP depletion, mitochondrial damage, cell cycle arrest in G2/M phase and enhanced ROS generation (leading to DNA damage) in a dose dependent fashion (195). These results were determined through changes in cell viability, cell morphology, oxidative stress and gel electrophoresis. TEM analysis confirmed that AgNPs were located in the mitochondria and nucleus, indicating a possible role of AgNPs in mitochondrial toxicity leading to DNA 
damage (195). The mechanism was hypothesized to be a disruption in the mitochondrial membrane that led to the formation of ROS and possible interruption of ATP synthesis.

Anionic clays (metal hydroxide nanoparticles) are another important class of nanomaterials for potential drug delivery applications. Choi et al., has conducted a toxicity study of anionic clay particles in human lung epithelial cells (A549) and normal (L-132) cells and compared them with HeLa cells and osteosarcoma cells (HOS) (196). Cell proliferation and cell viability data revealed low cytotoxicity associated with a dose of $<250 \mu \mathrm{g} / \mathrm{ml}$ within $48 \mathrm{~h}$. However, a treatment with a higher dose $(250-500 \mu \mathrm{g} / \mathrm{ml})$ for $72 \mathrm{~h}$ triggered an inflammatory response that differed in cell types (A549 > HOS > HeLa), interestingly the normal cells indicated no toxic effects (196). The mechanisms of toxicity among inorganic nanoparticles were found to be different from one system to the next. For example, single walled carbon nanotubes (SWNTs) caused oxidative stress, triggering apoptosis while magnetic nanoparticles induced cell death through membrane damage. Furthermore silica particles prompted an inflammatory response that did not cause cell death in normal or malignant cells (Fig 10). Ironically, anionic clay particles did not exhibit any toxic effects in terms of membrane disruption, apoptosis and ROS generation with the low dose listed above.

Magnetic nanoparticles (MNPs) can be formulated in many different ways for various biomedical applications. MNPs exhibit acute toxicity in vivo which has limited their clinical translation (197). Non-immunogenic responses in cells and macrophages is highly viable with MNP (20-45 $\mathrm{nm})$ treatments as evident by MTT assays and dose dependent apoptosis (Fig. 11) $(198,199)$. Oxidative stress and interference with mitochondrial energy production by MNPs can lead to cytotoxicity. Dextran coated MNPs showed a $\mathrm{LD}_{50}$ value of $400 \mathrm{mg} /$ $\mathrm{kg}$ in rats which caused cytotoxic effects on peritoneal cells, lymphocytes and neutrophils (200-202). Therefore, some formulated MNPs could be safer by tuning the surface chemistry.

\section{Challenges Ahead}

Tumor heterogeneity has complicated the continuous battle in the treatment of cancer. Every cancer is unique and differs from organ to organ. Cancer cells are heterogeneous in terms of genetic mutations and expression profiles. A tumor is a complicated mixture of malignant, non-malignant, stem and progenitor cells (203). This fact has posed a significant challenge to all researchers and clinicians to come up with a specific and targeted cancer therapy to combat non-specificity and therapeutic efficacy.

Inorganic nanoparticles could be useful to address cancer heterogeneity and applied for use in targeted therapy in specific tumor environments (tumor stroma). Understanding the interactions between the stromal cells and tumor cells is important to develop an effective therapeutic strategy. In general, tumor microenvironments contain leaky vasculature and high permeability due to more angiogenesis triggered by different cytokines (2). Nanoparticles can be used to passively target the tumors through this leaky vasculature due to the enhanced permeability and retention (EPR) effect $(2,204)$. Nanoparticles are ideal due to the ease at which anticancer agents, liposomes and macromolecules can be conjugated to the surface and promote accumulation in the tumor lesion. Unfortunately, the interstitial fluid pressure in the tumor is a constant threat for successful delivery of nanoconjugates using the EPR effect. However, normalization of tumor vasculature by anti-angiogenic therapy followed by administration of the nanoconjugates may offer better therapeutic efficacy (205).

Nanoparticles could also be utilized to site specifically target tumors in order to minimize the non-specificity of the drugs (206). Many cancer cells have an overexpression of different 
receptor proteins on the surface of cell membranes. To achieve an efficient targeting with improved therapeutic efficacy, selection of an appropriate therapeutic moiety, a targeting agent, size of the nanoconjugates, their hydrodynamic radius and hydrophilic properties should be considered.

\section{Conclusion}

Nanoparticles possess great potential for future clinical applications in imaging, diagnosis and therapeutics. However, the fundamental research and knowledge about their interactions with specific cells, the mechanism of entry, subcellular compartmentalization, and trafficking throughout the body are still unknown. These studies will help to understand the interactions and recognitions of the nanoparticle by the cells at the molecular level (207). Finally, all of this information will help rational design of nanoconjugates for combating various deadly diseases previously untreatable and ultimately improving the human health care system for future generations.

\section{Acknowledgments}

Partly supported by NIH CA135011 and CA136494 grants to PM

\section{References}

1. Giljohannand DA, Mirkin CA. Drivers of biodiagnostic development. Nature. 2009; 462:461-464. [PubMed: 19940916]

2. Patra CR, Bhattacharya R, Mukhopadhyay D, Mukherjee P. Application of gold nanoparticles for targeted therapy in cancer. J Biomed Nanotechnol. 2008; 4:99-132.

3. Paciotti GF, Myer L, Weinreich D, Goia D, Pavel N, McLaughlin RE, Tamarkin L. Colloidal gold: A novel nanoparticle vector for tumor directed drug delivery. Drug Deliv. 2004; 11:169-183. [PubMed: 15204636]

4. Mahdihassan S. Cinnabar-gold as the best alchemical drug of longevity, called Makaradhwaja in India. Am J Chin Med. 1985; 13:93-108. [PubMed: 3895885]

5. Danieland D, Astruc MC. Gold Nanoparticles: Assembly, Supramolecular Chemistry, QuantumSize-Related Properties, and Applications Toward Biology, Catalysis, and Nanotechnology. Chem Rev. 2004; 104:293-346. [PubMed: 14719978]

6. Frickerand RG, Buckley SP. Comparison of two colorimetric assays as cytotoxicity endpoints for an in vitro screen for antitumour agents. Anticancer Res. 1996; 16:3755-3760. [PubMed: 9042253]

7. Bhattacharyaand P, Mukherjee R. Biological properties of "naked" metal nanoparticles. Adv Drug Delivery Rev. 2008; 60:1289-1306.

8. Felson DT, Anderson JJ, Meenan RF. The comparative efficacy and toxicity of second-line drugs in rheumatoid arthritis: Results of two metaanalyses. Arthritis Rheum. 1990; 33:1449-1461. [PubMed: 1977391]

9. Frank Shaw C. Gold-Based Therapeutic Agents. Chem Rev. 1999; 99:2589-2600. [PubMed: 11749494]

10. Berners-Price SJ, Girard GR, Hill DT, Sutton BM, Jarrett PS, Faucette LF, Johnson RK, Mirabelli CK, Sadler PJ. Cytotoxicity and antitumor activity of some tetrahedral bis(diphosphino)gold(I) chelates. J Med Chem. 1990; 33:1386-1392. [PubMed: 2329559]

11. Berners-Priceand PJ, Sadler SJ. Interaction of the antitumor $\mathrm{Au}(\mathrm{I})$ complex with human blood plasma, red cells, and lipoproteins: H NMR studies. J Inorg Biochem. 1987; 31:267-281. [PubMed: 3437279]

12. Berners-Price SJ, Norman RE, Sadler PJ. The autoxidation and proton dissociation constants of tertiary diphosphines: relevance to biological activity. J Inorg Biochem. 1987; 31:197-209. [PubMed: 2828542]

13. Haiducand C, Silvestru I. Rhodium, iridium, copper and gold antitumor organometallic compounds (review). In Vivo. 1989; 3:285-294. [PubMed: 2519867] 
14. Mukherjee P, Bhattacharya R, Wang P, Wang L, Basu S, Nagy JA, Atala A, Mukhopadhyay D, Soker S. Antiangiogenic properties of gold nanoparticles. Clin Cancer Res. 2005; 11:3530-3534. [PubMed: 15867256]

15. Azzaroni O, Brown AA, Cheng N, Wei A, Jonas AM, Huck WTS. Synthesis of gold nanoparticles inside polyelectrolyte brushes. J Mat Chem. 2007; 17:3433-3439.

16. Esparza R, Rosas G, Lopez Fuentes M, Salnchez Ramilrez JF, Pal U, Ascencio JA, PeÌrez R. Synthesis of gold nanoparticles with different atomistic structural characteristics. Mater Charact. 2007; 58:694-700.

17. Tuvaland A, Gedanken T. A microwave-assisted polyol method for the deposition of silver nanoparticles on silica spheres. Nanotechnology. 2007; 18:255601-255608.

18. Jin Y, Wang P, Yin D, Liu J, Qin L, Yu N, Xie G, Li B. Gold nanoparticles prepared by sonochemical method in thiol-functionalized ionic liquid. Colloid Surf A: Physicochem Eng Aspects. 2007; 302:366-370.

19. Abyaneh MK, Paramanik D, Varma S, Gosavi SW, Kulkarni SK. Formation of gold nanoparticles in polymethylmethacrylate by UV irradiation. J Phys D: Appl Phys. 2007; 40:3771-3779.

20. Giorgetti E, Giusti A, Laza SC, Marsili P, Giammanco F. Production of colloidal gold nanoparticles by picosecond laser ablation in liquids. Phys Status Solidi A. 2007; 204:1693-1698.

21. Nakamoto M, Yamamoto M, Fukusumi M. Thermolysis of gold(I) thiolate complexes producing novel gold nanoparticles passivated by alkyl groups. Chem Commun (Camb). 2002:1622-1623. [PubMed: 12170812]

22. Mandal TK, Fleming MS, Walt DR. Preparation of Polymer Coated Gold Nanoparticles by Surface-Confined Living Radical Polymerization at Ambient Temperature. Nano Lett. 2002; 2:37.

23. Warren SC, Jackson AC, Cater-Cyker ZD, DiSalvo FJ, Wiesner U. Nanoparticle synthesis via the photochemical polythiol process. J Am Chem Soc. 2007; 129:10072-10073. [PubMed: 17655308]

24. Peter PE, John Meurig T. Gold in a Metallic Divided State - From Faraday to Present-Day Nanoscience13. Angew Chem Int Ed. 2007; 46:5480-5486.

25. Turkevich J, Stevenson PC, Hillier J. A study of the nucleation and growth processes in the synthesis of colloidal gold. Discuss Faraday Soc. 1951; 11:55-75.

26. Yonezawaand T, Kunitake T. Practical preparation of anionic mercapto ligand-stabilized gold nanoparticles and their immobilization. Colloid Surf A: Physicochem Eng Aspects. 1999; 149:193-199.

27. Brust M, Walker M, Bethell D, Schiffrin DJ, Whyman R. Synthesis of thiol-derivatised gold nanoparticles in a two-phase liquid-liquid system. J Chem Soc Chem Commun. 1994; 7:801-802.

28. Mukherjee P, Patra CR, Ghosh A, Kumar R, Sastry M. Characterization and catalytic activity of gold nanoparticles synthesized by autoreduction of aqueous chloroaurate ions with fumed silica. Chem Mater. 2002; 14:1678-1684.

29. Byrappa K, Ohara S, Adschiri T. Nanoparticles synthesis using supercritical fluid technology towards biomedical applications. Adv Drug Delivery Rev. 2008; 60:299-327.

30. Rowe MD, Thamm DH, Kraft SL, Boyes SG. Polymer-modified gadolinium metal-organic framework nanoparticles used as multifunctional nanomedicines for the targeted imaging and treatment of cancer. Biomacromolecules. 2009; 10:983-993. [PubMed: 19290624]

31. Mukherjee P, Ahmad A, Mandal D, Senapati S, Sainkar SR, Khan MI, Ramani R, Parischa R, Ajayakumar PV, Alam M, Sastry M, Kumar R. Bioreduction of AuCl4 - ions by the fungus, Verticillium sp. and surface trapping of the gold nanoparticles formed. Angew Chem Int Ed. 2001; 40:3585-3588.

32. Mukherjee P, Ahmad A, Mandal D, Senapati S, Sainkar SR, Khan MI, Parishcha R, Ajaykumar PV, Alam M, Kumar R, Sastry M. Fungus-Mediated Synthesis of Silver Nanoparticles and Their Immobilization in the Mycelial Matrix: A Novel Biological Approach to Nanoparticle Synthesis. Nano Lett. 2001; 1:515-519.

33. Rosiand CA, Mirkin NL. Nanostructures in biodiagnostics. Chem Rev. 2005; 105:1547-1562. [PubMed: 15826019]

34. Alivisatos P. The use of nanocrystals in biological detection. Nat Biotechnol. 2004; 22:47-52. [PubMed: 14704706] 
35. Katzand I, Willner E. Integrated nanoparticle-biomolecule hybrid systems: Synthesis, properties, and applications. Angew Chem Int Ed. 2004; 43:6042-6108.

36. Whitesides GM. The 'right' size in nanobiotechnology. Nat Biotechnol. 2003; 21:1161-1165. [PubMed: 14520400]

37. Linkand MA, El-Sayed S. Optical Properties and Ultrafast Dynamics of Metallic Nanocrystals. Ann Rev Physi Chem. 2003; 54:331-366.

38. Kelly KL, Coronado E, Zhao LL, Schatz GC. The optical properties of metal nanoparticles: The influence of size, shape, and dielectric environment. J Phys Chem B. 2003; 107:668-677.

39. Jain PK, ElSayed IH, El-Sayed MA. Au nanoparticles target cancer. Nano Today. 2007; 2:18-29.

40. Liz-Marzán LM. Nanometals: Formation and color. Mater Today. 2004; 7:26-31.

41. Jain PK, Lee KS, El-Sayed IH, El-Sayed MA. Calculated absorption and scattering properties of gold nanoparticles of different size, shape, and composition: Applications in biological imaging and biomedicine. J Phys Chem B. 2006; 110:7238-7248. [PubMed: 16599493]

42. Stober W, Fink A, Bohn E. Controlled growth of monodisperse silica spheres in the micron size range. J Colloid Interface Sci. 1968; 26:62-69.

43. Brongersma ML. Nanoscale photonics: Nanoshells: gifts in a gold wrapper. Nat Mater. 2003; 2:296-297. [PubMed: 12728232]

44. Linkand MA, El-Sayed S. Shape and size dependence of radiative, non-radiative and photothermal properties of gold nanocrystals. Int Revs Phys Chem. 2000; 19:409-453.

45. El-Sayed MA. Some interesting properties of metals confined in time and nanometer space of different shapes. Acc Chem Res. 2001; 34:257-264. [PubMed: 11308299]

46. Muller-Dethlefsand P, Hobza K. Noncovalent Interactions: A Challenge for Experiment and Theory. Chem Rev. 2000; 100:143-167. [PubMed: 11749236]

47. Sastry M, Rao M, Ganesh KN. Electrostatic assembly of nanoparticles and biomacromolecules. Acc Chem Res. 2002; 35:847-855. [PubMed: 12379137]

48. Levyand JN, Onuchic Y. Mechanisms of protein assembly: Lessons from minimalist models. Acc Chem Res. 2006; 39:135-142. [PubMed: 16489733]

49. Bain CD, Evall J, Whitesides GM. Formation of monolayers by the coadsorption of thiols on gold: variation in the head group, tail group, and solvent. J Am Chem Soc. 1989; 111:7155-7164.

50. Love JC, Estroff LA, Kriebel JK, Nuzzo RG, Whitesides GM. Self-assembled monolayers of thiolates on metals as a form of nanotechnology. Chem Rev. 2005; 105:1103-1169. [PubMed: 15826011]

51. Liu Y, Miyoshi H, Nakamura M. Nanomedicine for drug delivery and imaging: a promising avenue for cancer therapy and diagnosis using targeted functional nanoparticles. Int J Cancer. 120:2527-2537. [PubMed: 17390371]

52. Paunesku T, Ke T, Dharmakumar R, Mascheri N, Wu A, Lai B, Vogt S, Maser J, Thurn K, SzolcKowalska B, Larson A, Bergan RC, Omary R, Li D, Lu ZR, Woloschak GE. Gadoliniumconjugated $\mathrm{TiO} 2-\mathrm{DNA}$ oligonucleotide nanoconjugates show prolonged intracellular retention period and T1-weighted contrast enhancement in magnetic resonance images. Nanomedicine. 2008; 4:201-207. [PubMed: 18567541]

53. Warner JH, Hoshino A, Yamamoto K, Tilley RD. Water-soluble photoluminescent silicon quantum dots. Angew Chem Int Ed. 2005; 44:4550-4554.

54. Shubayev VI, Pisanic TR 2nd, Jin S. Magnetic nanoparticles for theragnostics. Adv Drug Deliv Rev. 2009; 61:467-477. [PubMed: 19389434]

55. Arbab AS, Liu W, Frank JA. Cellular magnetic resonance imaging: Current status and future prospects. Expert Rev Med Devices. 2006; 3:427-439. [PubMed: 16866640]

56. McCarthy JR, Kelly KA, Sun EY, Weissleder R. Targeted delivery of multifunctional magnetic nanoparticles. Nanomedicine. 2007; 2:153-167. [PubMed: 17716118]

57. Gao X, Cui Y, Levenson RM, Chung LWK, Nie S. In vivo cancer targeting and imaging with semiconductor quantum dots. Nat Biotechnol. 2004; 22:969-976. [PubMed: 15258594]

58. Thrall JH. Nanotechnology and Medicine. Radiology. 2004; 230:315-318. [PubMed: 14752175]

59. Jiang W, KimBetty YS, Rutka JT, Warren CCW. Nanoparticle-mediated cellular response is sizedependent. Nat Nanotechnol. 2008; 3:145-150. [PubMed: 18654486] 
60. Peng G, Tisch U, Adams O, Hakim M, Shehada N, Broza YY, Billan S, Abdah-Bortnyak R, Kuten A, Haick H. Diagnosing lung cancer in exhaled breath using gold nanoparticles. Nat Nanotechnol. 2009; 4:669-673. [PubMed: 19809459]

61. Smithpeter C, Dunn A, Drezek R, Collier T, Richards-Kortum R. Near real time confocal microscopy of cultured amelanotic cells: Sources of signal, contrast agents and limits of contrast. J Biomed Opt. 1998; 3:429-436.

62. Sokolov K, Follen M, Aaron J, Pavlova I, Malpica A, Lotan R, Richards-Kortum R. Real-Time Vital Optical Imaging of Precancer Using Anti-Epidermal Growth Factor Receptor Antibodies Conjugated to Gold Nanoparticles. Cancer Res. 2003; 63:1999-2004. [PubMed: 12727808]

63. Collier T, Lacy A, Richards-Kortum R, Malpica A, Follen M. Near real-time confocal microscopy of amelanotic tissue: Detection of dysplasia in ex vivo cervical tissue. Acad Radiol. 2003; 9:504512. [PubMed: 12458875]

64. Tearney GJ, Brezinski ME, Bouma BE, Boppart SA, Pitris C, Southern JF, Fujimoto JG. In vivo endoscopic optical biopsy with optical coherence tomography. Science. 1997; 276:2037-2039. [PubMed: 9197265]

65. Liang C, Descour MR, Sung KB, Richards-Kortum R. Fiber confocal reflectance microscope (FCRM) for in-vivo imaging. Opt Express. 2001; 9:821-830. [PubMed: 19424320]

66. Grizzle WE, Manne U, Jhala NC, Weiss HL. Molecular characterization of colorectal neoplasia in translational research. Arch Pathol Lab Med. 2001; 125:91-98. [PubMed: 11151060]

67. Maruo T, Yamasaki M, Ladines-Llave CA, Mochizuki M. Immunohistochemical demonstration of elevated expression of epidermal growth factor receptor in the neoplastic changes of cervical squamous epithelium. Cancer. 1992; 69:1182-1187. [PubMed: 1739918]

68. Goel R, Shah N, Visaria R, Paciotti GF, Bischof JC. Biodistribution of TNF- $\alpha$-coated gold nanoparticles in an in vivo model system. Nanomedicine. 2009; 4:401-410. [PubMed: 19505243]

69. Kumar R, Roy I, Ohulchanskky TY, Vathy LA, Bergey EJ, Sajjad M, Prasad PN. In Vivo Biodistribution and Clearance Studies Using Multimodal Organically Modified Silica Nanoparticles. ACS Nano. 2010; 4:699-708. [PubMed: 20088598]

70. Huang X, El-Sayed IH, Qian W, El-Sayed MA. Cancer cell imaging and photothermal therapy in the near-infrared region by using gold nanorods. J Am Chem Soc. 2006; 128:2115-2120. [PubMed: 16464114]

71. Aggarwal P, Hall JB, McLeland CB, Dobrovolskaia MA, McNeil SE. Nanoparticle interaction with plasma proteins as it relates to particle biodistribution, biocompatibility and therapeutic efficacy. Adv Drug Deliv Rev. 2009; 61:428-437. [PubMed: 19376175]

72. Fischer NO, McIntosh CM, Simard JM, Rotello VM. Inhibition of chymotrypsin through surface binding using nanoparticle-based receptors. Proc Natl Acad Sci U S A. 2002; 99:5018-5023. [PubMed: 11929986]

73. Peer D, Karp JM, Hong S, Farokhzad OC, Margalit R, Langer R. Nanocarriers as an emerging platform for cancer therapy. Nat Nanotechnol. 2007; 2:751-760. [PubMed: 18654426]

74. Hynesand HA, Lane NE. ERBB receptors and cancer: the complexity of targeted inhibitors. Nat Rev Cancer. 2005; 5:341-354. [PubMed: 15864276]

75. Herbst RS, Kim ES, Harari PM. IMC-C225, an anti-epidermal growth factor receptor monoclonal antibody, for treatment of head and neck cancer. Expert opin biol ther. 2001; 1:719-732. [PubMed: 11727507]

76. Patra CR, Bhattacharya R, Wang E, Katarya A, Lau JS, Dutta S, Muders M, Wang S, Buhrow SA, Safgren SL, Yaszemski MJ, Reid JM, Ames MM, Mukherjee P, Mukhopadhyay D. Targeted delivery of gemcitabine to pancreatic adenocarcinoma using cetuximab as a targeting agent. Cancer Res. 2008; 68:1970-1978. [PubMed: 18339879]

77. Toffoli G, Cernigoi C, Russo A, Gallo A, Bagnoli M, Boiocchi M. Overexpression of folate binding protein in ovarian cancers. Int J Cancer. 1997; 74:193-198. [PubMed: 9133455]

78. Coney LR, Tomassetti A, Carayannopoulos L, Frasca V, Kamen BA, Colnaghi MI, Zurawski VR Jr. Cloning of a tumor-associated antigen: MOv18 and MOv19 antibodies recognize a folatebinding protein. Cancer Res. 1991; 51:6125-6132. [PubMed: 1840502] 
79. Parker N, Turk MJ, Westrick E, Lewis JD, Low PS, Leamon CP. Folate receptor expression in carcinomas and normal tissues determined by a quantitative radioligand binding assay. Anal Biochem. 2005; 338:284-293. [PubMed: 15745749]

80. Gabizon A, Shmeeda H, Horowitz AT, Zalipsky S. Tumor cell targeting of liposome-entrapped drugs with phospholipid-anchored folic acid-PEG conjugates. Adv Drug Delivery Rev. 2004; 56:1177-1192.

81. Elnakatand M, Ratnam H. Distribution, functionality and gene regulation of folate receptor isoforms: Implications in targeted therapy. Adv Drug Delivery Rev. 2004; 56:1067-1084.

82. Kamenand AK, Smith BA. A review of folate receptor alpha cycling and 5-methyltetrahydrofolate accumulation with an emphasis on cell models in vitro. Adv Drug Delivery Rev. 2004; 56:10851097.

83. Dixit V, Van Den Bossche J, Sherman DM, Thompson DH, Andres RP. Synthesis and grafting of thioctic acid-PEG-folate conjugates onto Au nanoparticles for selective targeting of folate receptor-positive tumor cells. Bioconjugate Chem. 2006; 17:603-609.

84. Guo H, Qian H, Idris NM, Zhang Y. Singlet oxygen-induced apoptosis of cancer cells using upconversion fluorescent nanoparticles as a carrier of photosensitizer. Nanomedicine. 2010; 6:486-495. [PubMed: 20044035]

85. Wu Q, Cao H, Luan Q, Zhang J, Wang Z, Warner JH, Watt AA. Biomolecule-assisted synthesis of water-soluble silver nanoparticles and their biomedical applications. Inorg Chem. 2008; 47:58825888. [PubMed: 18498157]

86. Melnikov OV, Gorbenko OY, Markelova MN, Kaul AR, Atsarkin VA, Demidov VV, Soto C, Roy EJ, Odintsov BM. Ag-doped manganite nanoparticles: New materials for temperature-controlled medical hyperthermia. J Biomed Mater Res A. 2009; 91:1048-1055. [PubMed: 19127514]

87. Rieter WJ, Pott KM, Taylor KM, Lin W. Nanoscale coordination polymers for platinum-based anticancer drug delivery. J Am Chem Soc. 2008; 130:11584-11585. [PubMed: 18686947]

88. Dhar S, Gu FX, Langer R, Farokhzad OC, Lippard SJ. Targeted delivery of cisplatin to prostate cancer cells by aptamer functionalized Pt(IV) prodrug-PLGA-PEG nanoparticles. Proc Natl Acad Sci U S A. 2008; 105:17356-17361. [PubMed: 18978032]

89. Jabr-Milane LS, van Vlerken LE, Yadav S, Amiji MM. Multi-functional nanocarriers to overcome tumor drug resistance. Cancer Treat Rev. 2008; 34:592-602. [PubMed: 18538481]

90. Bussolino F, Mantovani A, Persico G. Molecular mechanisms of blood vessel formation, Trends. Biochem Sci. 1997; 22:251-256.

91. Risau W. Mechanisms of angiogenesis. Nature. 1997; 386:671-674. [PubMed: 9109485]

92. Ferraraand WJ, Henzel N. Pituitary follicular cells secrete a novel heparin-binding growth factor specific for vascular endothelial cells. Biochem Biophys Res Commun. 1989; 161:851-858. [PubMed: 2735925]

93. Guptaand RY, Qin MK. Mechanism and its regulation of tumor-induced angiogenesis. World J Gastroenterol. 2003; 9:1144-1155. [PubMed: 12800214]

94. Nyberg P, Xie L, Kalluri R. Endogenous inhibitors of angiogenesis. Cancer Res. 2005; 65:39673979. [PubMed: 15899784]

95. Senger DR, Galli SJ, Dvorak AM, Perruzzi CA, Susan Harvey V, Dvorak HF. Tumor cells secrete a vascular permeability factor that promotes accumulation of ascites fluid. Science. 1983; 219:983-985. [PubMed: 6823562]

96. Folkman J. Tumor angiogensis: role in regulation of tumor growth. The symposium/The Society for Developmental Biology Society for Developmental Biology Symposium. 1974; 30:43-52. [PubMed: 4600889]

97. Folkman J. Tumor angiogenesis factor. Cancer Res. 1974; 34:2109-2113. [PubMed: 4842257]

98. Yorozuya K, Kubota T, Watanabe M, Hasegawa H, Ozawa S, Kitajima M, Chikahisa LM, Yamada Y. TSU-68 (SU6668) inhibits local tumor growth and liver metastasis of human colon cancer xenografts via anti-angiogenesis. Oncol rep. 2005; 14:677-682. [PubMed: 16077974]

99. Kerbel RS. Antiangiogenic Drugs and Current Strategies for the Treatment of Lung Cancer. Seminars in Oncology. 2004; 31:54-60. [PubMed: 14981581] 
100. Woude GFV, Kelloff GJ, Ruddon RW, Koo H-M, Sigman CC, Barrett JC, Day RW, Dicker AP, Kerbel RS, Parkinson DR, Slichenmyer WJ. Reanalysis of Cancer Drugs. Clinical Cancer Res. 2004; 10:3897-3907. [PubMed: 15173099]

101. Bhattacharya R, Patra CR, Verma R, Kumar S, Greipp PR, Mukherjee P. Gold nanoparticles inhibit the proliferation of multiple myeloma cells. Adv Mater. 2007; 19:711-716.

102. Hideshima T, Bradner JE, Wong J, Chauhan D, Richardson P, Schreiber SL, Anderson KC. Small-molecule inhibition of proteasome and aggresome function induces synergistic antitumor activity in multiple myeloma. Proc Natil Acad Sci of the U S A. 2005; 102:8567-8572.

103. Hideshima T, Chauhan D, Richardson P, Anderson KC. Identification and validation of novel therapeutic targets for multiple myeloma. J Clin Oncol. 2005; 23:6345-6350. [PubMed: 16155018]

104. Richardson PG, Mitsiades C, Hideshima T, Anderson KC. Bortezomib: Proteasome inhibition as an effective anticancer therapy. Annu Rev Med. 2006; 57:33-47. [PubMed: 16409135]

105. Mukherjee P, Bhattacharya R, Bone N, Lee YK, Patra C, Wang S, Lu L, Secreto C, Banerjee PC, Yaszemski MJ, Kay NE, Mukhopadhyay D. Potential therapeutic application of gold nanoparticles in B-chronic lymphocytic leukemia (BCLL): Enhancing apoptosis. J Nanobiotechnology. 2007; 5:1-13. [PubMed: 17295922]

106. Van Hoe L, Van Cutsem E, Vergote I, Marchal G, Baert AL. Reporting on the results of cancer treatment in patients with metastatic liver disease: proposal of symmetric size-dependent CTcriteria for response. Ann Oncol. 1996; 7:871-872. [PubMed: 8922207]

107. Donaldson SS. Nutritional consequences of radiotherapy. Cancer Res. 1977; 37:2407-2413. [PubMed: 861954]

108. Hamiltonand G, Hortobagyi A. Chemotherapy: What progress in the last 5 years? J Clin Oncol. 2005; 23:1760-1775. [PubMed: 15755984]

109. Mirza AN, Fornage BD, Sneige N, Kuerer HM, Newman LA, Ames FC, Singletary SE. Radiofrequency ablation of solid tumors. Cancer J. 2001; 7:95-102. [PubMed: 11324771]

110. Overgaard J. The current and potential role of hyperthermia in radiotherapy. Int J Radiat Oncol Biol Phys. 1989; 16:535-549. [PubMed: 2646256]

111. Westermann AM, Jones EL, Schem BC, Van Der Steen-Banasik EM, Koper P, Mella O, Uitterhoeve ALJ, De Wit R, Van Der Velden J, Burger C, Van Der Wilt CL, Dahl O, Prosnitz LR, Van Der Zee J. First results of triple-modality treatment combining radiotherapy, chemotherapy, and hyperthermia for the treatment of patients with stage IIB, III, and IVA cervical carcinoma. Cancer. 2005; 104:763-770. [PubMed: 15968685]

112. Bertone V, Barni S, Silvotti MG, Freitas I, Mathe G, Pontiggia P. Hyperthermic effects on the human metastatic liver: A TEM study. Anticancer Res. 1997; 17:4713-4716. [PubMed: 9494594]

113. He X, Wolkers WF, Crowe JH, Swanlund DJ, Bischof JC. In situ thermal denaturation of proteins in dunning AT-1 prostate cancer cells: implication for hyperthermic cell injury. Ann Biomed Eng. 2004; 32:1384-1398. [PubMed: 15535056]

114. Christophi C, Winkworth A, Muralihdaran V, Evans P. The treatment of malignancy by hyperthermia. J Surg Oncol. 1998; 7:83-90.

115. Jordan A, Scholz R, Wust P, Fahling H, Krause J, Wlodarczyk W, Sander B, Vogl T, Felix R. Effects of Magnetic Fluid Hyperthermia (MFH) on C3H mammary carcinoma in vivo. Int $\mathbf{J}$ Hyperthermia. 1997; 13:587-605. [PubMed: 9421741]

116. Linkand MA, El-Sayed S. Spectral Properties and Relaxation Dynamics of Surface Plasmon Electronic Oscillations in Gold and Silver Nanodots and Nanorods. J Phys Chem B. 1999; 103:8410-8426.

117. El-Sayed IH, Huang X, El-Sayed MA. Surface plasmon resonance scattering and absorption of anti-EGFR antibody conjugated gold nanoparticles in cancer diagnostics: Applications in oral cancer. Nano lett. 2005; 5:829-834. [PubMed: 15884879]

118. El-Sayed IH, Huang X, El-Sayed MA. Selective laser photo-thermal therapy of epithelial carcinoma using anti-EGFR antibody conjugated gold nanoparticles. Cancer Lett. 2006; 239:129-135. [PubMed: 16198049] 
119. Huang X, Jain PK, El-Sayed IH, El-Sayed MA. Determination of the minimum temperature required for selective photothermal destruction of cancer cells with the use of immunotargeted gold nanoparticles. Photochem Photobiol. 2006; 82:412-417. [PubMed: 16613493]

120. Gupta AK, Naregalkar RR, Vaidya VD, Gupta M. Recent advances on surface engineering of magnetic iron oxide nanoparticles and their biomedical applications. Nanomedicine. 2007; 2:2339. [PubMed: 17716188]

121. Lu AH, Salabas EL, Schuth F. Magnetic nanoparticles: Synthesis, protection, functionalization, and application. Angew Chem Int Ed. 2007; 46:1222-1244.

122. Huber DL. Synthesis, properties, and applications of iron nanoparticles. Small. 2005; 1:482-501. [PubMed: 17193474]

123. Guptaand M, Gupta AK. Synthesis and surface engineering of iron oxide nanoparticles for biomedical applications. Biomaterials. 2005; 26:3995-4021. [PubMed: 15626447]

124. Shinkai M. Functional magnetic particles for medical application. J Biosci Bioeng. 2002; 94:606613. [PubMed: 16233357]

125. Nam JM, Thaxton CS, Mirkin CA. Nanoparticle-based bio-bar codes for the ultrasensitive detection of proteins. Science. 2003; 301:1884-1886. [PubMed: 14512622]

126. Hirsch LR, Stafford RJ, Bankson JA, Sershen SR, Rivera B, Price RE, Hazle JD, Halas NJ, West JL. Nanoshell-mediated near-infrared thermal therapy of tumors under magnetic resonance guidance. Proc Natl Acad Sci U S A. 2003; 100:13549-13554. [PubMed: 14597719]

127. Visaria RK, Griffin RJ, Williams BW, Ebbini ES, Paciotti GF, Song CW, Bischof JC. Enhancement of tumor thermal therapy using gold nanoparticle-assisted tumor necrosis factor- $\alpha$ delivery. Mol Cancer Ther. 2006; 5:1014-1020. [PubMed: 16648573]

128. Cheng FY, Chen CT, Yeh CS. Comparative efficiencies of photothermal destruction of malignant cells using antibody-coated silica@ Au nanoshells, hollow Au/Ag nanospheres and Au nanorods. Nanotechnology. 2009; 20:425104. [PubMed: 19779243]

129. Thevenot P, Cho J, Wavhal D, Timmons RB, Tang L. Surface chemistry influences cancer killing effect of TiO2 nanoparticles. Nanomedicine. 2008; 4:226-236. [PubMed: 18502186]

130. Farrer NJ, Salassa L, Sadler PJ. Photoactivated chemotherapy (PACT): the potential of excitedstate d-block metals in medicine. Dalton Trans. 2009:10690-10701. [PubMed: 20023896]

131. Juban EA, Smeigh AL, Monat JE, McCusker JK. Ultrafast dynamics of ligand-field excited states. Coordination Chem Rev. 2006; 250:1783-1791.

132. Loganathanand H, Morrison D. 'Photocisplatin' reagents. Curr Opin Drug Discovery Dev. 2005; 8:478-486.

133. Moore CM, Pendse D, Emberton M. Photodynamic therapy for prostate cancer - A review of current status and future promise. Nat Clin Pract Urol. 2009; 6:18-30. [PubMed: 19132003]

134. Paradies J, Crudass J, MacKay F, Yellowlees LJ, Montgomery J, Parsons S, Oswald I, Robertson N, Sadler PJ. Photogeneration of titanium(III) from titanium(IV) citrate in aqueous solution. J Inorg Biochem. 2006; 100:1260-1264. [PubMed: 16603248]

135. Sam M, Hwang JH, Chanfreau G, Abu-Omar MM. Hydroxyl radical is the active species in photochemical DNA strand scission by bis(peroxo)vanadium(V) phenanthroline. Inorg Chem. 2004; 43:8447-8455. [PubMed: 15606193]

136. Billadeauand H, Morrison MA. Photoaquation of cis-dichlorobis-(1,10phenanthroline)chromium(III) and the photochemical and thermal reactions of this complex with native calf- thymus DNA. J Inorg Biochem. 2005; 57:249-270.

137. Banfi S, Cassani E, Caruso E, Cazzaro M. Oxidative cleavage of plasmid bluescript by watersoluble Mn-porphyrins and artificial oxidants or molecular oxygen. Bioorg Med Chem. 2003; 11:3595-3605. [PubMed: 12901904]

138. Niesel J, Pinto A, Peindy N'Dongo HW, Merz K, Ott I, Gust R, Schatzschneider U. Photoinduced $\mathrm{CO}$ release, cellular uptake and cytotoxicity of a tris(pyrazolyl)methane (tpm) manganese tricarbonyl complex. Chem Comm. 2008; 15:1798-1800. [PubMed: 18379697]

139. Maurer TD, Kraft BJ, Lato SM, Ellington AD, Zaleski JM. Photoactivated DNA cleavage via charge transfer promoted $\mathrm{N} 2$ release from tris[3-hydroxy-1,2,3-benzotriazine-4(3H)one]iron(III). Chem Comm. 2000:69-70. 
140. Magennis SW, Habtemariam A, Novakova O, Henry JB, Meier S, Parsons S, Oswald IDH, Brabec V, Sadler PJ. Dual triggering of DNA binding and fluorescence via photoactivation of a dinuclear ruthenium(II) arene complex. Inorg Chem. 2007; 46:5059-5068. [PubMed: 17497848]

141. Blower PJ, Dilworth JR, Maurer RI, Mullen GD, Reynolds CA, Zheng Y. Towards new transition metal-based hypoxic selective agents for therapy and imaging. J Inorg Biochem. 2001; 85:15-22. [PubMed: 11377691]

142. Failes TW, Cullinane C, Diakos CI, Yamamoto N, Lyons JG, Hambley TW. Studies of a cobalt(III) complex of the MMP inhibitor marimastat: A potential hypoxia-activated prodrug. Chemistry. 2007; 13:2974-2982. [PubMed: 17171733]

143. Mitchell JB, Wink DA, DeGraff W, Gamson J, Keefer LK, Krishna MC. Hypoxic mammalian cell radiosensitization by nitric oxide. Cancer res. 1993; 53:5845-5848. [PubMed: 8261391]

144. Boyd S, Ghiggino KP, McFadyen WD. Photochemistry of anthracene-appended cobalt(III) cyclam complexes. Australian J Chem. 2008; 61:585-591.

145. Funston AM, Cullinane C, Ghiggino KP, McFadyen WD, Stylli SS, Tregloan PA. Dipyridophenazine complexes of cobalt(III): DNA photocleavage and photobiology. Australian J Chem. 2005; 58:206-212.

146. Zeglisand JK, Barton BM. DNA base mismatch detection with bulky rhodium intercalators: Synthesis and applications. Nat Protoc. 2007; 2:357-371. [PubMed: 17406597]

147. Prabhakaraand HSB, Naik MC. Mixed ligand Ni(II) complexes: DNA binding, oxidative and photo-cleavage studies. Main Group Chem. 2008; 7:97-107.

148. Bednarski PJ, Mackay FS, Sadler PJ. Photoactivatable platinum complexes. AntiCancer Agents Med Chem. 2007; 7:75-93. [PubMed: 17266506]

149. MacKay FS, Farrer NJ, Salassa L, Tai HC, Deeth RJ, Moggach SA, Wood PA, Parsons S, Sadler PJ. Synthesis, characterisation and photochemistry of PtIV pyridyl azido acetato complexes. Dalton Trans. 2009:2315-2325. [PubMed: 19290364]

150. Weersink RA, Bogaards A, Gertner M, Davidson SRH, Zhang K, Netchev G, Trachtenberg J, Wilson BC. Techniques for delivery and monitoring of TOOKAD (WST09)-mediated photodynamic therapy of the prostate: Clinical experience and practicalities. J Photochem Photobiol B. 2005; 79:211-222. [PubMed: 15896648]

151. Lahiri D, Bhowmick T, Pathak B, Shameema O, Patra AK, Ramakumar S, Chakravarty AR. Anaerobic photocleavage of DNA in red light by dicopper(1l) complexes of 3,3'dithiodipropionic acid. Inorga Chem. 2009; 48:339-349.

152. Rzigalinskiand JS, Strobl BA. Cadmium-containing nanoparticles: Perspectives on pharmacology and toxicology of quantum dots. Toxicol Appl Pharmacol. 2009; 238:280-288. [PubMed: 19379767]

153. Anas A, Akita H, Harashima H, Itoh T, Ishikawa M, Biju V. Photosensitized breakage and damage of DNA by CdSe-ZnS quantum dots. J Phys Chem B. 2008; 112:10005-10011. [PubMed: 18582008]

154. Juzenas P, Chen W, Sun YP, Coelho MAN, Generalov R, Generalova N, Christensen IL. Quantum dots and nanoparticles for photodynamic and radiation therapies of cancer. Adv Drug Delivery Rev. 2008; 60:1600-1614.

155. Juzenas P, Generalov R, Juzeniene A, Moan J. Generation of nitrogen oxide and oxygen radicals by quantum dots. J Biomed Nanotechnol. 2008; 4:450-456.

156. Andrews GA, Root SW, Kerman HD, Bigelow RR. Intracavitary Colloidal Radiogold in the Treatment of Effusions Caused By Malignant Neoplasms. Ann Surg. 1953; 137:375-381. [PubMed: 13031468]

157. Wheeler HB, Jaques WE, Botsford TW. Experiences With the Use of Radioactive Colloidal Gold in the Treatment of Cancer. Ann Surg. 1955; 141:208-217. [PubMed: 13229255]

158. Buchsbaumand WC, Keettel HJ. Radioisotopes in treatment of stage 1a ovarian cancer. National Cancer Institute Monograph No 1975. 1975; 42:127-128.

159. Rogoff EE, Romano R, Hahn EW. The prevention of Ehrlich ascites tumor using intraperitoneal colloidal. Dose vs. size of inoculum. Radiol. 1975; 114:225-226.

160. Hainfeld JF, Slatkin DN, Focella TM, Smilowitz HM. Gold nanoparticles: A new X-ray contrast agent. Br J Radiol. 2006; 79:248-253. [PubMed: 16498039] 
161. Chanda N, Kan P, Watkinson LD, Shukla R, Zambre A, Carmack TL, Engelbrecht H, Lever JR, Katti K, Fent GM, Casteel SW, Smith CJ, Miller WH, Jurisson S, Boote E, Robertson JD, Cutler C, Dobrovolskaia M, Kannan R, Katti KV. Radioactive gold nanoparticles in cancer therapy: therapeutic efficacy studies of GA-(198)AuNP nanoconstruct in prostate tumor-bearing mice. Nanomedicine. 2010; 6:201-209. [PubMed: 19914401]

162. Diagaradjane P, Shetty A, Wang JC, Elliott AM, Schwartz J, Shentu S, Park HC, Deorukhkar A, Stafford RJ, Cho SH, Tunnell JW, Hazle JD, Krishnan S. Modulation of in vivo tumor radiation response via gold nanoshell-mediated vascular-focused hyperthermia: characterizing an integrated antihypoxic and localized vascular disrupting targeting strategy. Nano Lett. 2008; 8:1492-1500. [PubMed: 18412402]

163. Porcel E, Liehn S, Remita H, Usami N, Kobayashi K, Furusawa Y, Le Sech C, Lacombe S. Platinum nanoparticles: a promising material for future cancer therapy? Nanotechnology. 2010; 21:85103. [PubMed: 20101074]

164. Kobayashi K, Usami N, Sasaki I, Frohlich H, Le Sech C. Study of Auger effect in DNA when bound to molecules containing platinum. A possible application to hadrontherapy. Nucl Instr Method Physics Research Section B: Beam Interactions with Materials and Atoms. 2003; 199:348-355.

165. Meng-Ya C, Ai-Li S, Yu-Hung C, Chih-Jui C, Helen HWC, Chao-Liang W. Increased apoptotic potential and dose-enhancing effect of gold nanoparticles in combination with single-dose clinical electron beams on tumor-bearing mice. Cancer Sci. 2008; 99:1479-1484. [PubMed: 18410403]

166. Oleinick NL, Morris RL, Belichenko I. The role of apoptosis in response to photodynamic therapy: What, where, why, and how. Photochem Photobiol Sci. 2002; 1:1-21. [PubMed: 12659143]

167. Zhang P, Rogelj S, Nguyen K, Wheeler D. Design of a highly sensitive and specific nucleotide sensor based on photon upconverting particles. J Am Chem Soc. 2006; 128:12410-12411. [PubMed: 16984179]

168. Kramer KW, Biner D, Frei G, Gu del HU, Hehlen MP, Luthi SR. Hexagonal Sodium Yttrium Fluoride Based Green and Blue Emitting Upconversion Phosphors. Chem Mater. 2004; 16:12441251.

169. Roy I, Ohulchanskyy TY, Pudavar HE, Bergey EJ, Oseroff AR, Morgan J, Dougherty TJ, Prasad PN. Ceramic-based nanoparticles entrapping water-insoluble photosensitizing anticancer drugs: a novel drug-carrier system for photodynamic therapy. J Am Chem Soc. 2003; 125:7860-7865. [PubMed: 12823004]

170. Bechet D, Couleaud P, Frochot C, Viriot ML, Guillemin F, Barberi-Heyob M. Nanoparticles as vehicles for delivery of photodynamic therapy agents. Trends Biotechnol. 2008; 26:612-621. [PubMed: 18804298]

171. Wang X, Liu F, Andavan GTS, Jing X, Singh K, Yazdanpanah VR, Bruque N, Pandey RR, Lake R, Ozkan M, Wang KL, Ozkan CS. Carbon nanotube-DNA nanoarchitectures and electronic functionality. Small. 2006; 2:1356-1365. [PubMed: 17192987]

172. Chenand J, Zhang W. Using nanoparticles to enable simultaneous radiation and photodynamic therapies for cancer treatment. J Nanosci Nanotechnol. 2006; 6:1159-1166. [PubMed: 16736782]

173. Valko M, Leibfritz D, Moncol J, Cronin MTD, Mazur M, Telser J. Free radicals and antioxidants in normal physiological functions and human disease. Int J Biochemi Cell Biol. 2007; 39:44-84.

174. Yin JJ, Lao F, Meng J, Fu PP, Zhao Y, Xing G, Gao X, Sun B, Wang PC, Chen C, Liang XJ. Inhibition of tumor growth by endohedral metallofullerenol nanoparticles optimized as reactive oxygen species scavenger. Mol Pharmacol. 2008; 74:1132-1140. [PubMed: 18635669]

175. Colon J, Herrera L, Smith J, Patil S, Komanski C, Kupelian P, Seal S, Jenkins DW, Baker CH. Protection from radiation-induced pneumonitis using cerium oxide nanoparticles. Nanomedicine. 2009; 5:225-231. [PubMed: 19285453]

176. Tarnuzzer RW, Colon J, Patil S, Seal S. Vacancy Engineered Ceria Nanostructures for Protection from Radiation-Induced Cellular Damage. Nano Lett. 5:2573-2577. [PubMed: 16351218] 
177. Korsvik C, Patil S, Seal S, Self WT. Superoxide dismutase mimetic properties exhibited by vacancy engineered ceria nanoparticles. Chem Commun (Camb). 2007:1056-1058. [PubMed: 17325804]

178. Silver S, Phung LT, Silver G. Silver as biocides in burn and wound dressings and bacterial resistance to silver compounds. J Ind Microbiol Biotechnol. 2006; 33:627-634. [PubMed: 16761169]

179. Wadheraand A, Fung M. Systemic argyria associated with ingestion of colloidal silver. Dermatology online journal. Dermatol. 2005; 11:12.

180. Klasen HJ. Historical review of the use of silver in the treatment of burns. I. Early uses. Burns. 2000; 26:117-130. [PubMed: 10716354]

181. Atiyeh BS, Costagliola M, Hayek SN, Dibo SA. Effect of silver on burn wound infection control and healing: Review of the literature. Burns. 2007; 33:139-148. [PubMed: 17137719]

182. Elechiguerra JL, Burt JL, Morones JR, Camacho-Bragado A, Gao X, Lara HH, Yacaman MJ. Interaction of silver nanoparticles with HIV-1. J Nanobiotechnol. 2005:3-6.

183. Hall MD, Mellor HR, Callaghan R, Hambley TW. Basis for design and development of platinum(IV) anticancer complexes. J Med Chem. 2007; 50:3403-3411. [PubMed: 17602547]

184. Gao J, Liang G, Zhang B, Kuang Y, Zhang X, Xu B. FePt yolk-shell nanocrystals as a potent agent to kill HeLa cells. J Am Chem Soc. 2007; 129:1428-1433. [PubMed: 17263428]

185. Xu C, Yuan Z, Kohler N, Kim J, Chung MA, Sun S. FePt yonanoparticles as an Fe reservoir for controlled Fe release and tumor inhibition. J Am Chem Soc. 2009; 131:15346-15351. [PubMed: 19795861]

186. Xu C, Wang B, Sun S. Dumbbell-like Au-Fe3O4 Nanoparticles for Target-Specific Platin Delivery. J Am Chem Soc. 2009; 131:4216-4217. [PubMed: 19275156]

187. Xu ZP, Zeng QH, Lu GQ, Yu AB. Inorganic nanoparticles as carriers for efficient cellular delivery. Chem Eng Sci. 2006; 61:1027-1040.

188. Widder KJ, Morris RM, Poore GA. Selective targeting of magnetic albumin microspheres containing low-doses doxorubicin: Total remission in Yoshida sarcoma-bearing rats. Eur J Cancer Clin Oncol. 1983; 19:135-139. [PubMed: 6682771]

189. Zhu SG, Xiang JJ, Li XL, Shen SR, Lu HB, Zhou J, Xiong W, Zhang BC, Nie XM, Zhou M, Tang K, Li GY. Poly(L-lysine)-modified silica nanoparticles for the delivery of antisense oligonucleotides. Biotechnol Appl Biochem. 2004; 39:179-187. [PubMed: 15032738]

190. Bisht S, Bhakta G, Mitra S, Maitra A. pDNA loaded calcium phosphate nanoparticles: highly efficient non-viral vector for gene delivery. Int J Pharm. 2005; 288:157-168. [PubMed: 15607268]

191. Chowdhury EH, Kunou M, Nagaoka M, Kundu AK, Hoshiba T, Akaike T. High-efficiency gene delivery for expression in mammalian cells by nanoprecipitates of $\mathrm{Ca}-\mathrm{Mg}$ phosphate. Gene. 2004; 341:77-82. [PubMed: 15474290]

192. Alivisatos AP, Gu W, Larabell C. QUANTUM DOTS AS CELLULAR PROBES. Annu Rev Biomed Eng. 2005; 7:55-76. [PubMed: 16004566]

193. Oyewumi MO, Yokel RA, Jay M, Coakley T, Mumper RJ. Comparison of cell uptake, biodistribution and tumor retention of folate-coated and PEG-coated gadolinium nanoparticles in tumor-bearing mice. J Control Release. 2004; 95:613-626. [PubMed: 15023471]

194. Dobrovolskaiaand SE, McNeil MA. Immunological properties of engineered nanomaterials. Nat Nanotechnol. 2007; 2:469-478. [PubMed: 18654343]

195. AshaRani PV, Mun GLK, Hande MP, Valiyaveettil S. Cytotoxicity and genotoxicity of silver nanoparticles in human cells. ACS Nano. 2009; 3:279-290. [PubMed: 19236062]

196. Choi SJ, Oh JM, Choy JH. Toxicological effects of inorganic nanoparticles on human lung cancer A549 cells. J Inorg Biochem. 2009; 103:463-471. [PubMed: 19181388]

197. Kim JS, Yoon TJ, Yu KN, Kim BG, Park SJ, Kim HW, Lee KH, Park SB, Lee JK, Cho MH. Toxicity and tissue distribution of magnetic nanoparticles in mice. Toxicol Sci. 2006; 89:338347. [PubMed: 16237191]

198. Jengand J, Swanson HA. Toxicity of metal oxide nanoparticles in mammalian cells. J Environ Sci Health Part A: Toxic/Hazard Subst Environ Eng. 2006; 41:2699-2711. 
199. Gajdosikova A, Gajdosik AA, Koneracka M, Zavisova V, Stvrtina S, Krchnarova V, Kopcansky $\mathrm{P}$, Tomasovicova N, Stolc S, Timko M. Acute toxicity of magnetic nanoparticles in mice. Neuro endocrinol Lett. 2006; 27:96-99. [PubMed: 17159789]

200. Jain TK, Reddy MK, Morales MA, Leslie-Pelecky DL, Labhasetwar V. Biodistribution, clearance, and biocompatibility of iron oxide magnetic nanoparticles in rats. Mol Pharm. 2008; 5:316-327. [PubMed: 18217714]

201. Lacava LM, Garcia VAP, Kuckelhaus S, Azevedo RB, Sadeghiani N, Buske N, Morais PC, Lacava ZGM. Long-term retention of dextran-coated magnetite nanoparticles in the liver and spleen. J Magn Magn Mater. 2004:272-276. 2434-2435.

202. Yu Z, Xiaoliang W, Xuman W, Hong X, Hongchen G. Acute toxicity and irritation of waterbased dextran-coated magnetic fluid injected in mice. J Biomed Mater Res. 2008; 85:582-587.

203. Heppner GH. Tumor heterogeneity. Cancer Res. 1984; 44:2259-2265. [PubMed: 6372991]

204. Jain RK. Transport of molecules, particles, and cells in solid tumors. Annu rev biomed eng. 1999; 1:241-263. [PubMed: 11701489]

205. Jainand TP, Padera RK. Development. Lymphatics make the break. Science. 2003; 299:209-210. [PubMed: 12522236]

206. Koo OM, Rubinstein I, Onyuksel H. Role of nanotechnology in targeted drug delivery and imaging: a concise review. Nanomedicine. 2005; 1:193-212. [PubMed: 17292079]

207. Bhattacharyya S, Bhattacharya R, Curley S, McNiven MA, Mukherjee P. Nanoconjugation modulates the trafficking and mechanism of antibody induced receptor endocytosis. Proc Natl Acad Sci U S A. 2010; 107:14541-14546. [PubMed: 20679244] 

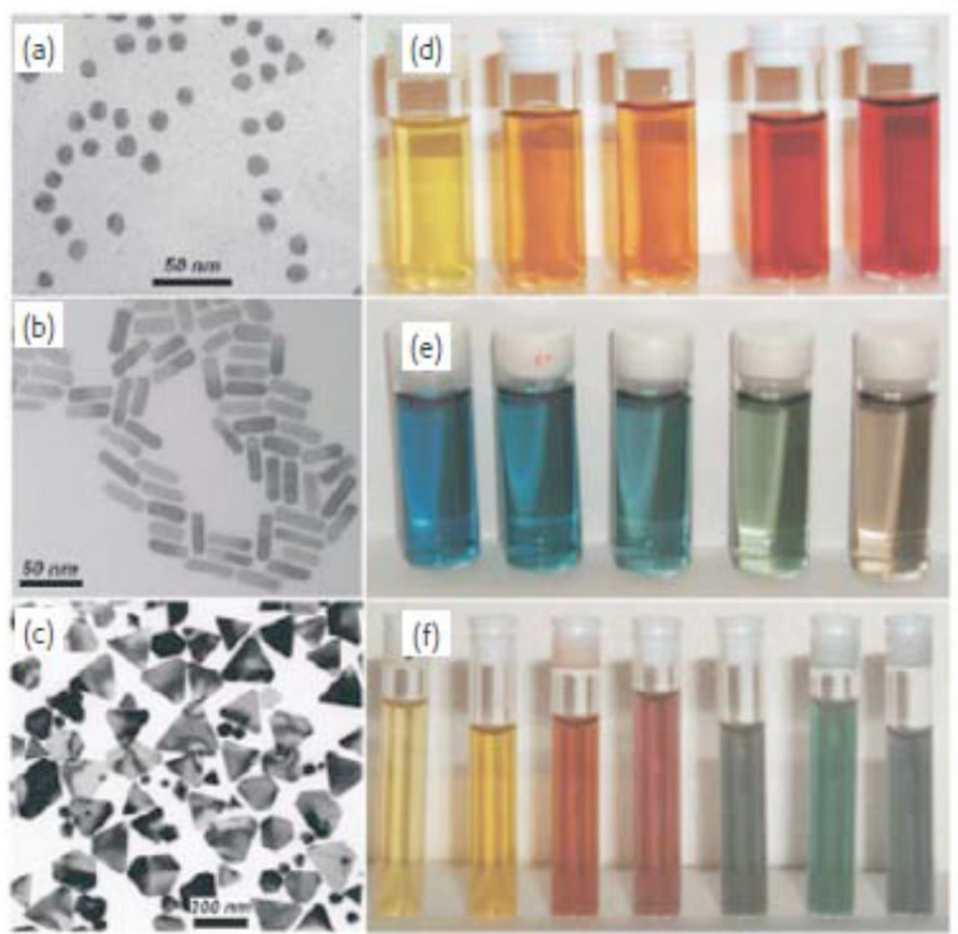

Figure 1.

Left: Transmission electron micrographs of Au nanospheres and nanorods (a, b) and Ag nanoprisms (c, mostly truncated triangles) formed using citrate reduction, seeded growth, and DMF reduction, respectively. Right: Photographs of colloidal dispersions of $\mathrm{Au}-\mathrm{Ag}$ alloy nanoparticles with increasing Au concentration (d), Au nanorods of increasing aspect ratio (e), and Ag nanoprisms with increasing lateral size (f). Reprinted with permission from Ref [40], Marzan et al., Nanometals: Formation and color. Materials Today. 7, 26 (2004). Copyright (C) 2004, Elsevier Limited. 


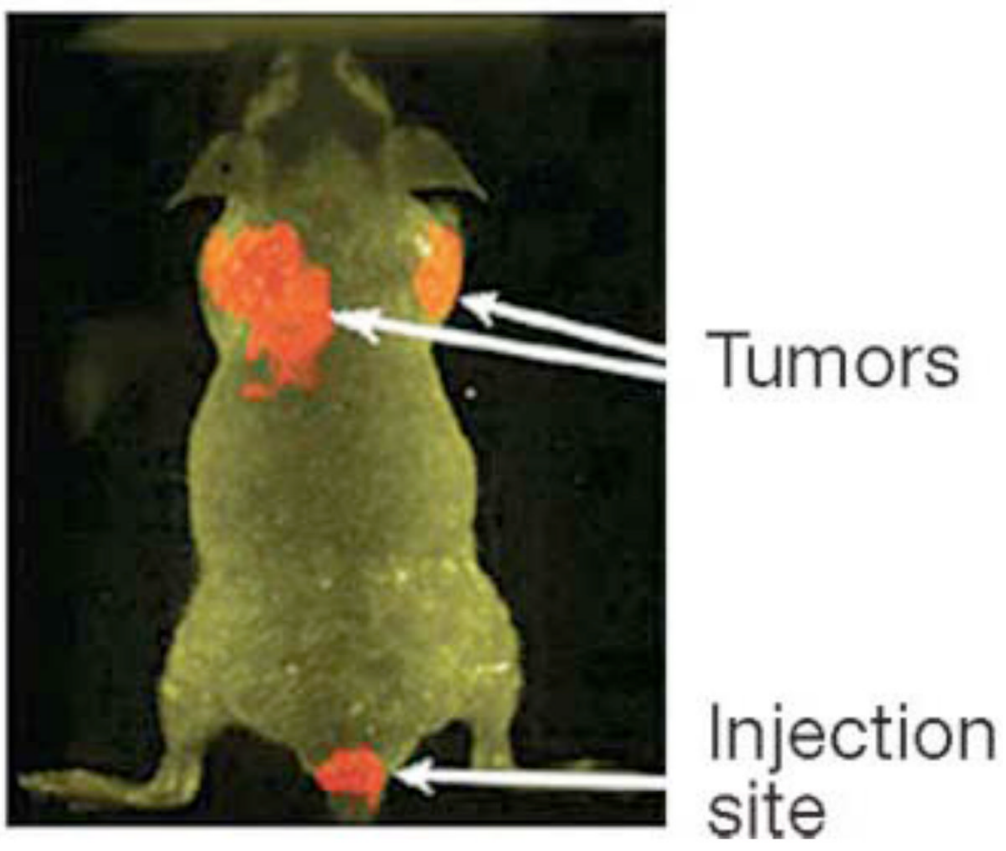

Figure 2.

In vivo fluorescence images of tumor-bearing mice using Qdot probes with anti-PEG-PSMA antibody conjugates surface modifications in mouse cancer model (PSMA: Prostate specific membrane antigen). In vivo fluorescence imaging was carried out using a macroillumination system. Reprinted with permission from Ref [57], Gao et al., In vivo cancer targeting and imaging with semiconductor quantum dots. Nat Biotech. 22, 969 (2004). Copyright (C 2004, Nature publishing group. 

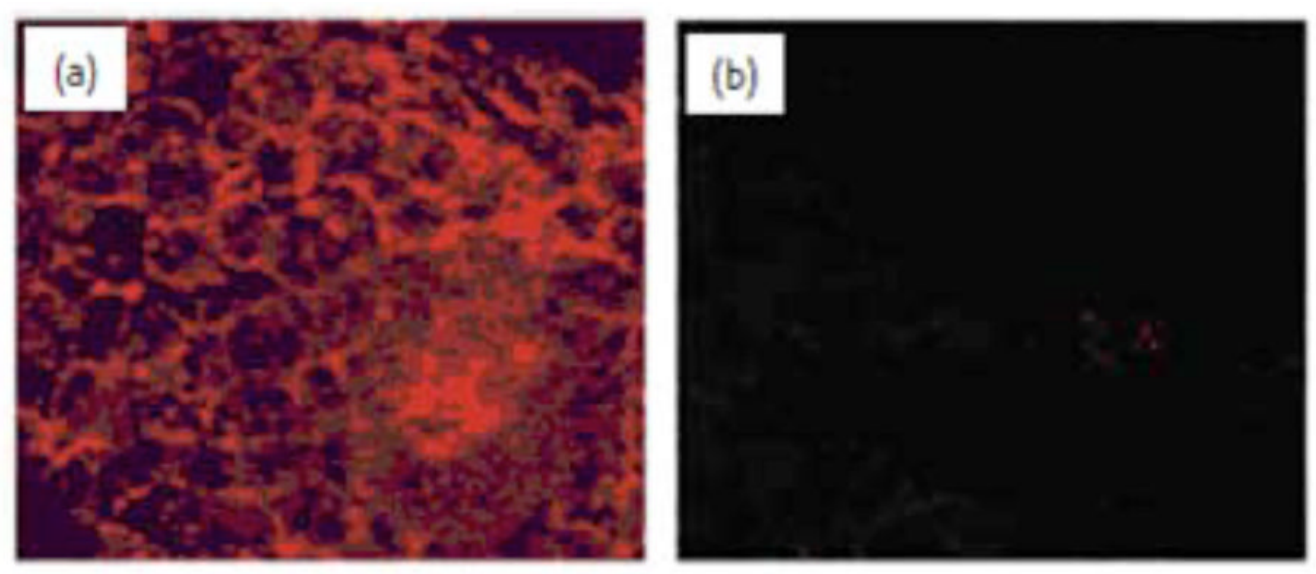

Figure 3.

Laser scanning confocal reflectance images of (a) precancerous and (b) normal fresh cervical ex vivo tissue labeled with anti-EGFR/Au nanoparticle bioconjugates. The images were obtained with $647 \mathrm{~nm}$ excitation wavelength, and are false-colored in red. Reprinted with permission from Ref [62], Sokolov et al., Real-Time Vital Optical Imaging of Precancer Using Anti-Epidermal Growth Factor Receptor Antibodies Conjugated to Gold Nanoparticles. Cancer Res. 63, 1999 (2003). Copyright @ 2003, American Association for Cancer Research. 


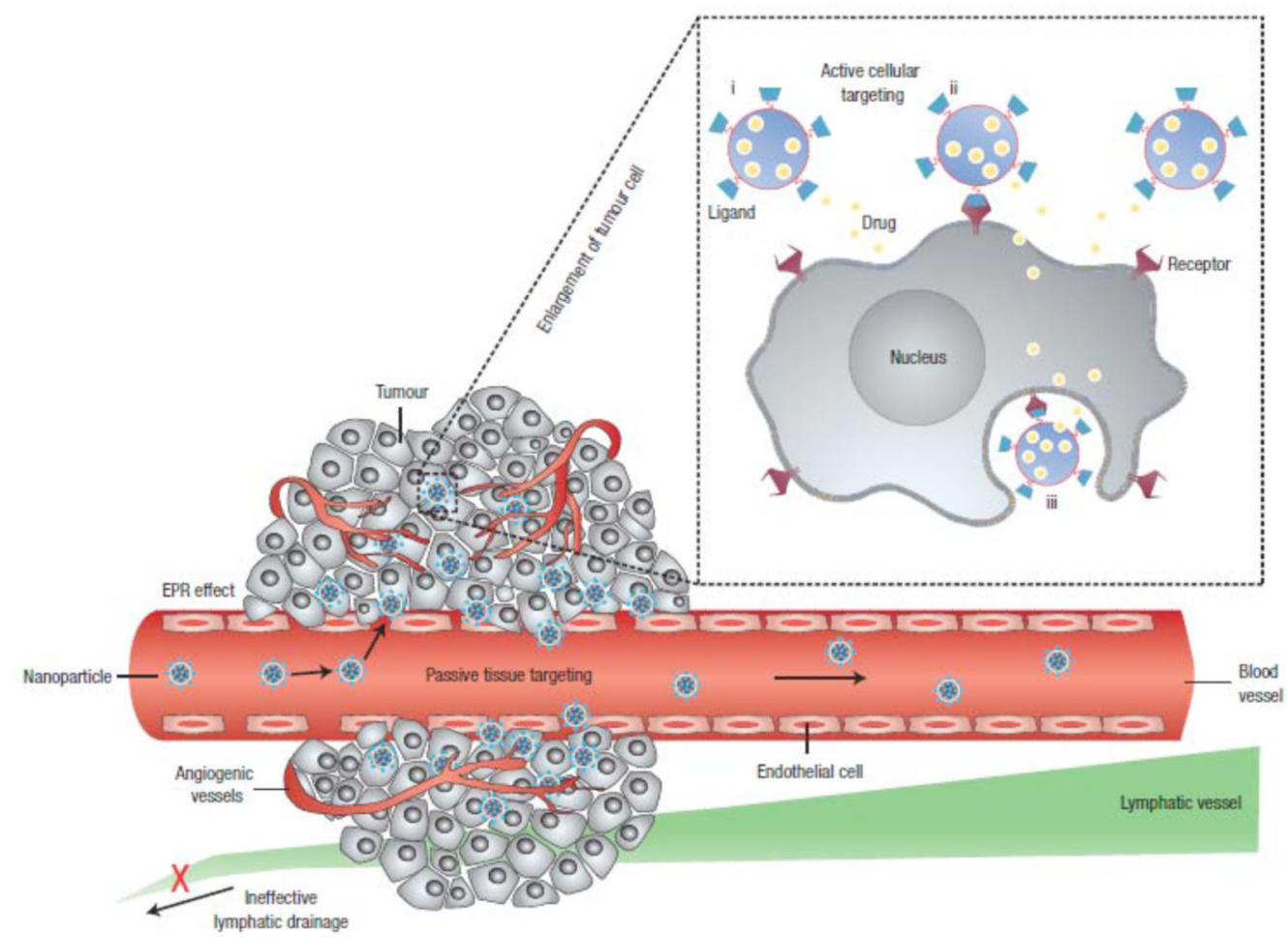




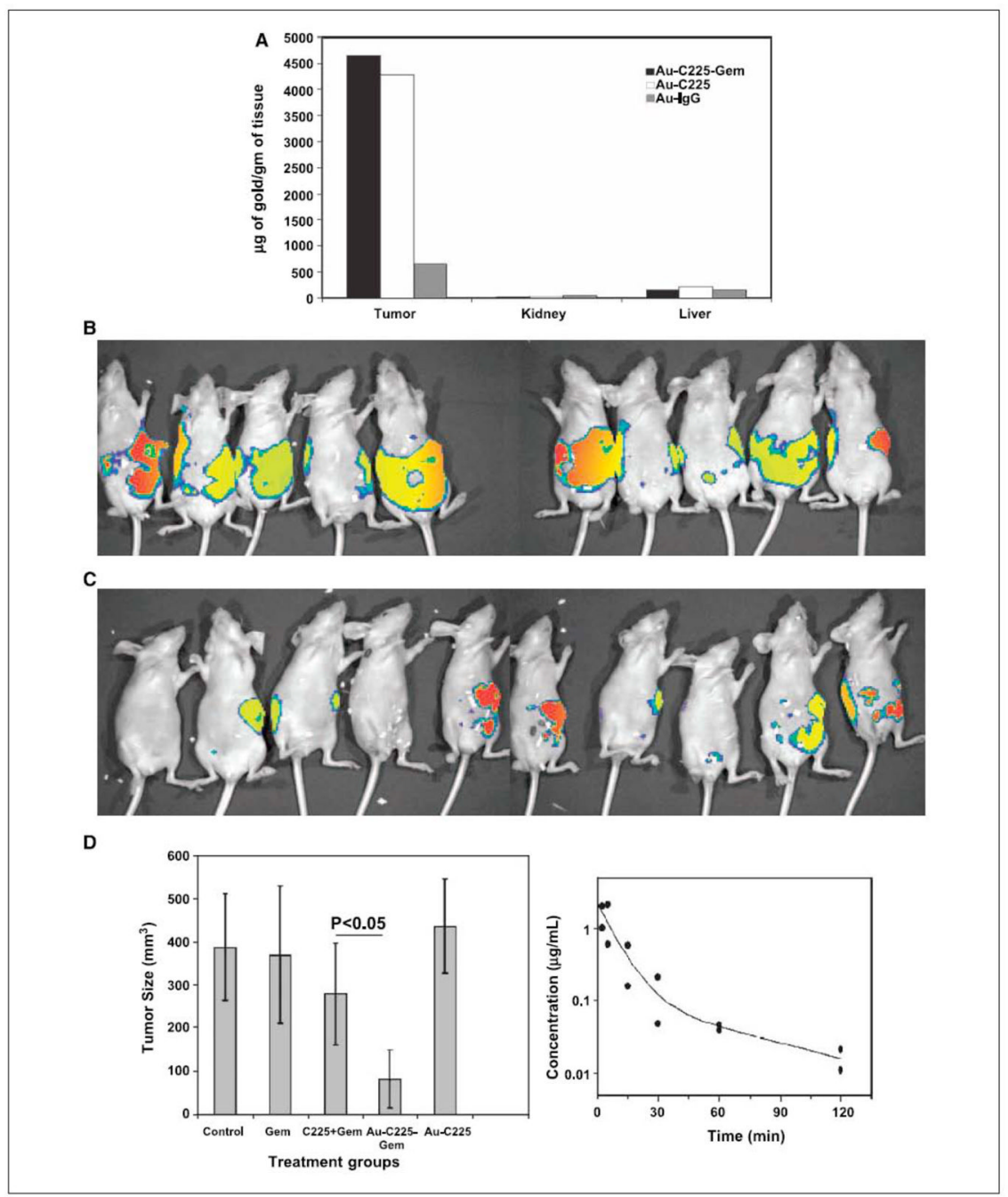

Figure 4.

Polymeric nanoparticles are shown as representative nanocarriers (circles). Passive tissue targeting is achieved by extravasation of nanoparticles through increased permeability of the tumour vasculature and ineffective lymphatic drainage (EPR effect). Active cellular targeting (inset) can be achieved by functionalizing the surface of nanoparticles with ligands that promote cell-specific recognition and binding. The nanoparticles can (i) release their contents in close proximity to the target cells; (ii) attach to the membrane of the cell and act as an extracellular sustained-release drug depot; or (iii) internalize into the cell. Reprinted with permission from Ref [73], Langer et al. Nanocarriers as an emerging platform for cancer therapy. Nature Nanotechnology 2, 751 (2007). (C) 2010 Nature Publishing Group. Figure 4A: In vivo targeting of the nanoconjugate and its therapeutic efficacy. $A$, the quantification of the amount of gold taken up by the tumor, kidney, and liver under different treatment groups $(n=3)$. A comparative bioluminescence image from the mice treated with a mixture of $\mathrm{C} 225$ and gemcitabine $(\mathrm{C} 225+\mathrm{Gem} ; B)$ or Au-C225-Gem $(C)$ i.p. $(n=10)$. $D$, effect of different treatment groups on tumor growth inhibition in vivo (left). Tumor volume was measured after sacrificing the mice at the end of the experiment. Right, plasma concentration of gold over time determined by ICP analysis. Blood samples were collected from the mice under isoflurane anesthesia at different time points in heparinized tubes containing tetrahydrouridine to prevent gemcitabine degradation by cytidine deaminase after 
i.v. drug administration. Reprinted with permission from Ref [76], Patra et al., Selective laser photo-thermal therapy of epithelial carcinoma using anti-EGFR antibody conjugated gold nanoparticles. Cancer Res. 68, 1970 (2008). Copyright $@$ 2008, American Association for Cancer Research. 


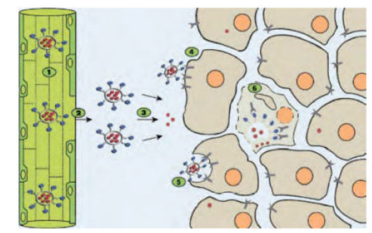

Figure 5.

Schematic drawing illustrating the concept of folate targeting of liposomes to tumor cells. The blue dots represent the liposomal folate ligands. The red dots represent the drug molecules encapsulated in the liposome water phase. The various steps involved in the targeting process are numerically designated from 1 to 6 . Steps $1-3$ are common to nontargeted and targeted liposomes. Steps 4-6 are specific to FTL. (1) Liposomes with longcirculating properties increase the number of passages through the tumor microvasculature. (2) Increased vascular permeability in tumor tissue enables properly downsized liposomes to extravasate and reach the tumor interstitial fluid. (3) Drug is gradually released from liposomes remaining in the interstitial fluid and enters tumor cells as free drug to exert a cytotoxic effect. (4) Other liposomes bind to the FR expressed on the tumor cell membrane via the folate ligand. Because of the limited diffusion capacity of liposomes, binding is likely to be limited to those tumor cells in closest vicinity to blood vessels. (5) Liposomes are internalized by tumor cells via FRME. (6) Internalized liposomes release their drug content in the cytosol enabling the drug to exert its cytotoxic effect. Reprinted with permission from Ref [81], Ratnam et al. Tumor cell targeting of liposome-entrapped drugs with phospholipid-anchored folic acid-PEG conjugates. Adv Drug Deliv Rev. 56, 1177 (2004). C2004, Elsevier Limited. 

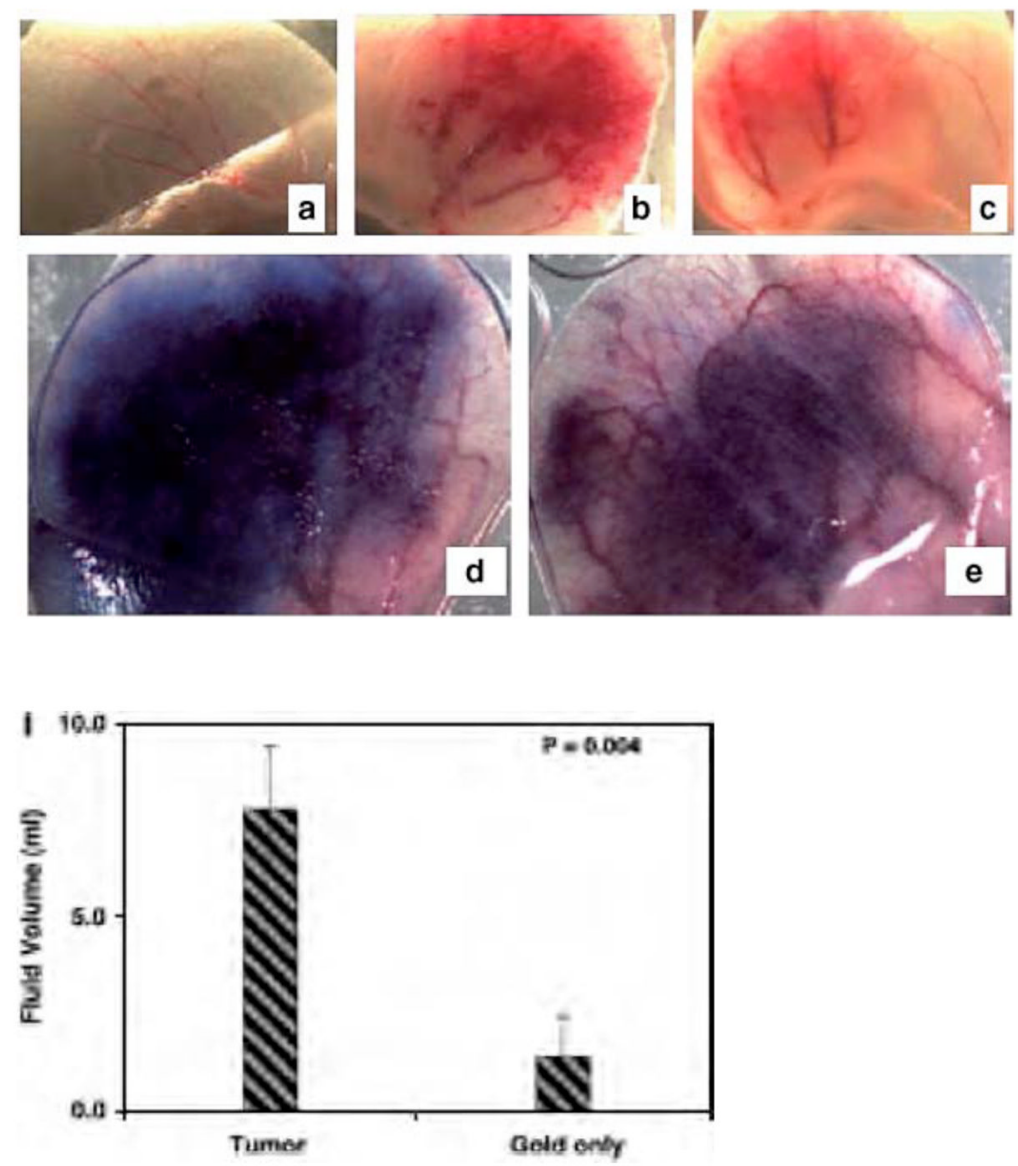

Figure 6.

Effect of nanogold on angiogenesis in vivo in the ears of nude mice. Gross appearance of angiogenesis 7 days (see Materials and Methods) after injection of nanogold only $(A)$, AdVEGF only $(B)$, nanogold and Ad-VEGF $(C)$. Giemsa stained $1 \mu \mathrm{mol} / \mathrm{L}$ epon sections of the ears were photographed at $10 \times$ magnifications, nanogold only. $(G)$, nanogold and Ad-VEGF $(H)$, ascites fluid accumulation in the peritoneal cavity $(I)$. Reprinted with permission from [14], Mukherjee et al. Antiangiogenic Properties of Gold Nanoparticles. Clin Cancer Res. 11, 3530 (2005). C2004, American Association for Cancer Research. 

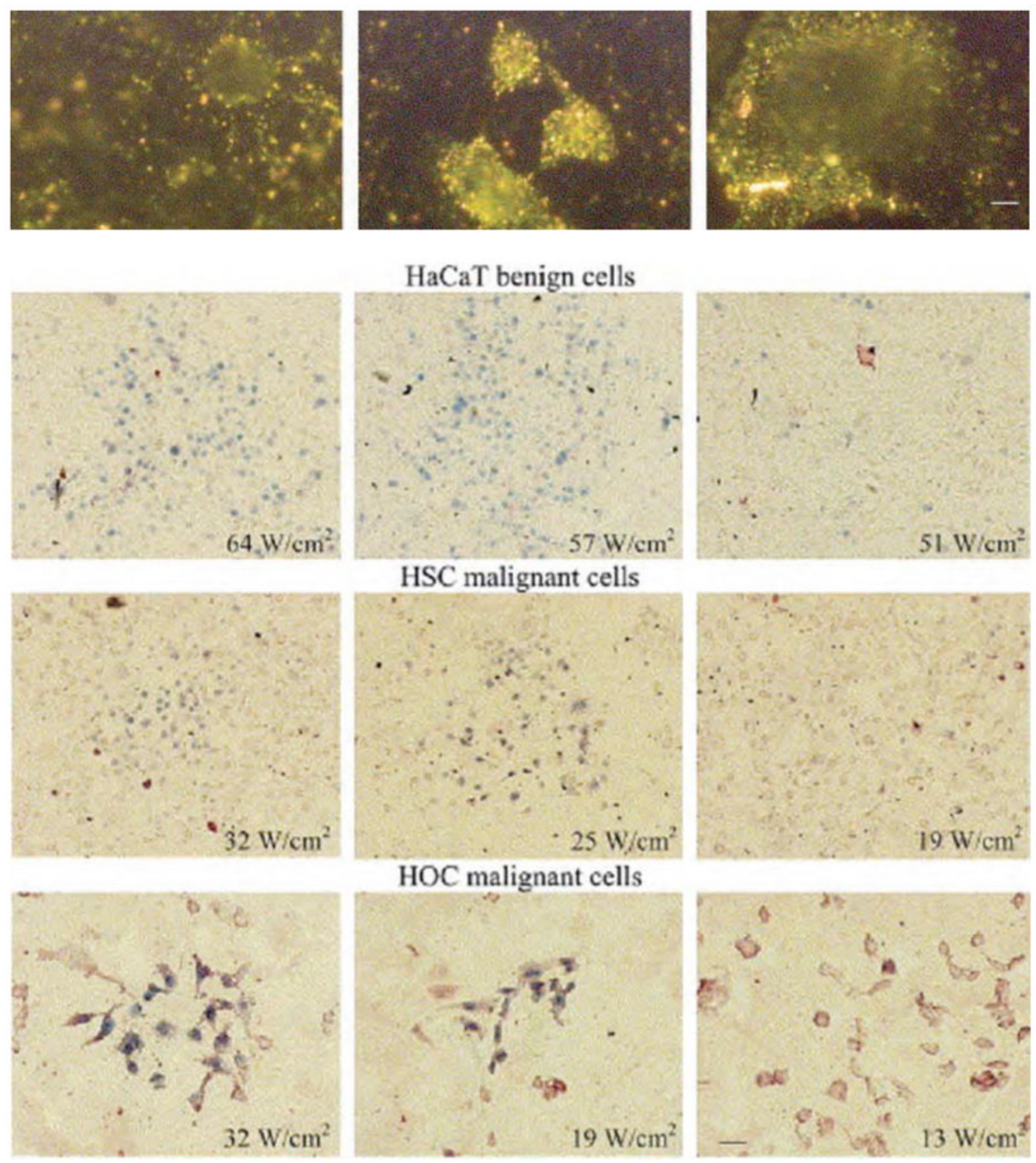

Figure 7.

Light scattering images of HaCaT benign cells (left), HSC malignant cells (middle) and HOC malignant cells (right) after incubation with anti-EGFR antibody conjugated gold nanoparticles. The figure shows clearly distinguished difference for the scattering images between the benign and malignant cells. The conjugated nanoparticles bind specifically with high concentrations to the surface of the malignant cells. Scale bar: $10 \mu \mathrm{m}$ for all images. $\mathrm{HaCaT}$ benign cells (top row), HSC malignant cells (middle row) and HOC malignant cells (bottom row) irradiated at different laser powers and then stained with trypan blue. HaCaT benign cells were killed at and above $57 \mathrm{~W} / \mathrm{cm}^{2}$, HSC malignant cells were killed at and above $25 \mathrm{~W} / \mathrm{cm}^{2}$ and HOC malignant cells were killed at and above $19 \mathrm{~W} / \mathrm{cm}^{2}$. Scale bar: $60 \mu \mathrm{m}$ for all images (For interpretation of the reference to color in this legend, the reader is referred to the web version of this article). Reprinted with permission from Ref [118], I.H. El-Sayed et al., Selective laser photo-thermal therapy of epithelial carcinoma using antiEGFR antibody conjugated gold nanoparticles. Cancer Lett. 239, 129 (2006). Copyright (C) 2006, Elsevier limited. 


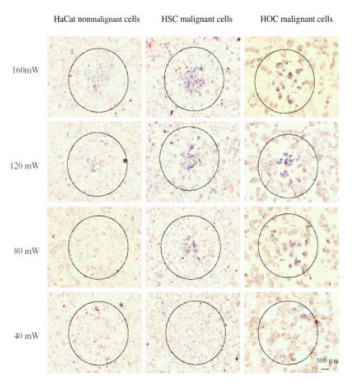

Figure 8.

Selective photothermal therapy of cancer cells with anti-EGFR/Au nanorods incubated. The circles show the laser spots on the samples. At $80 \mathrm{~mW}\left(10 \mathrm{~W} / \mathrm{cm}^{2}\right)$, the HSC and HOC malignant cells are obviously injured while the HaCat normal cells are not affected. The HaCat normal cells start to be injured at $120 \mathrm{~mW}\left(15 \mathrm{~W} / \mathrm{cm}^{2}\right)$ and are obviously injured at $160 \mathrm{~mW}\left(20 \mathrm{~W} / \mathrm{cm}^{2}\right)$. Reprinted with permission from Ref [70], H. Huang et al., Cancer Cell Imaging and Photothermal Therapy in the Near-Infrared Region by Using Gold Nanorods. J. Am. Chem. Soc. 128, 2115 (2006). (C) 2006, American Chemical Society. 


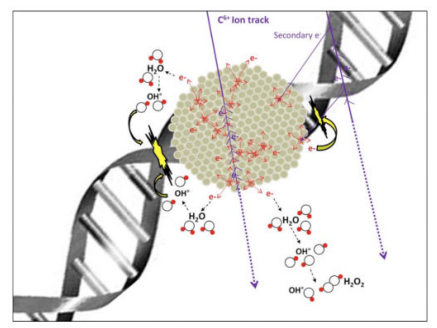

Figure 9.

Fast processes $(t<10-12 \mathrm{~s})$ involved in platinum nanoparticles excited by ionizing radiations. Reprinted with permission from Ref [163], Porcel et al. Platinum nanoparticles: a promising material for future cancer therapy. Nanotechnology. 21, 1 (2010). Copyright (C) 2010, IOP publishing limited. 


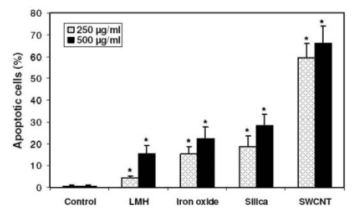

Fig. 10.

Apoptosis of A549 cells incubated with nanoparticles: LMH (A), iron oxide (B), silica (C), SWCNT (D), and \% apoptotic cells (E). Cells $\left(2 \times 10^{4}\right.$ cells $\left./ \mathrm{ml}\right)$ were exposed to nanoparticles (250-500 $\mathrm{lg} / \mathrm{ml})$ for $72 \mathrm{~h}$ and apoptotic cells were measured by annexin VFITC (green) binding assay. The nuclei were stained with Dapi (blue) or PI (red). Cell membrane partially stained by annexin V-FITC was indicated by the arrow. *Significant difference from control $(\mathrm{p}<0.05)$. Reprinted with permission from Ref [196], Choi et al., Toxicological effects of inorganic nanoparticles on human lung cancer A549 cells. J. Inorg. Biochem. 239, 129 (2009). Copyright $@ 2006$, Elsevier limited. 


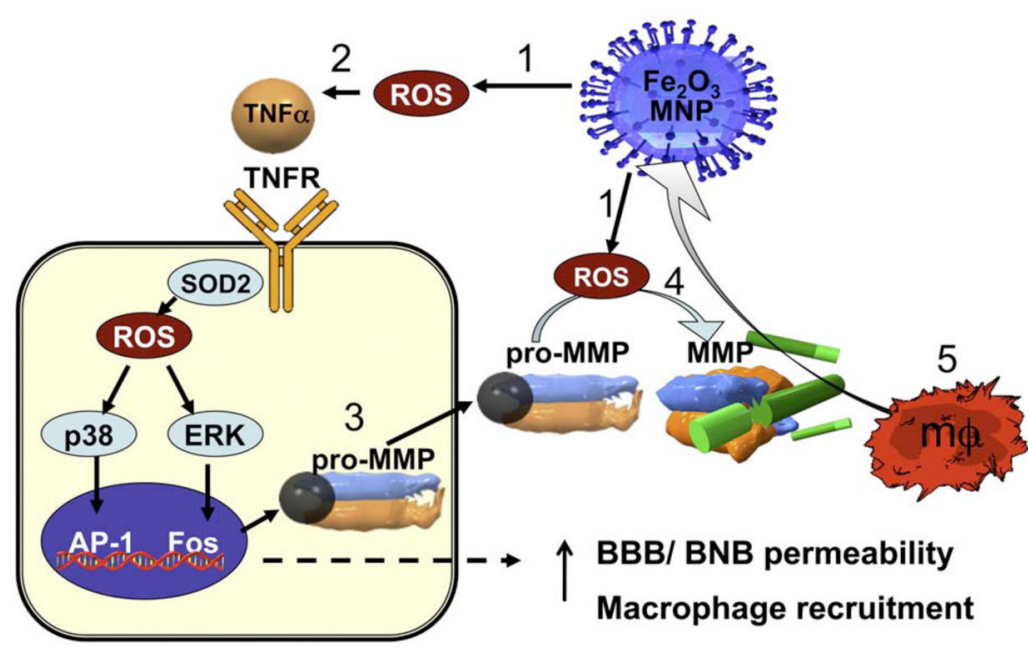

Fig. 11.

A proposed mechanism of MNP-induced macrophage recruitment into neuronal tissues. (1) Exposure to cytotoxic MNPs stimulated the formation of ROS in resident cells.(2) ROS promotes expression and release of proinflammatory cytokines, such as TNF- $\alpha$. Through its two receptors (TNFR), TNF- $\alpha$ activates p38 and ERK mitogen-activated protein kinases pathways to (3) induce the expression of matrix metalloproteinases (MMPs) in its inactive, pro-MMP form. In addition, (4) ROS can directly promote MMP activation from pro-form. MMPs are the only enzymes in the body capable of degrading blood-brain and blood-nerve barriers (BBB/BNB), which (5) promotes infiltration of circulatingmacrophages $(\mathrm{m} \Phi)$ into neuronal tissues. MNP size and surface chemistry determines the mechanisms and the target cells of MNP internalization, as well as extent of neurotoxicity of MNPs. Reprinted with permission from Ref [54], Shubayev et al., Magnetic nanoparticles for theragnostics. $A d v$ Drug Del Rev. 61, 467 (2009). Copyright (C) 2009, Elsevier limited. 


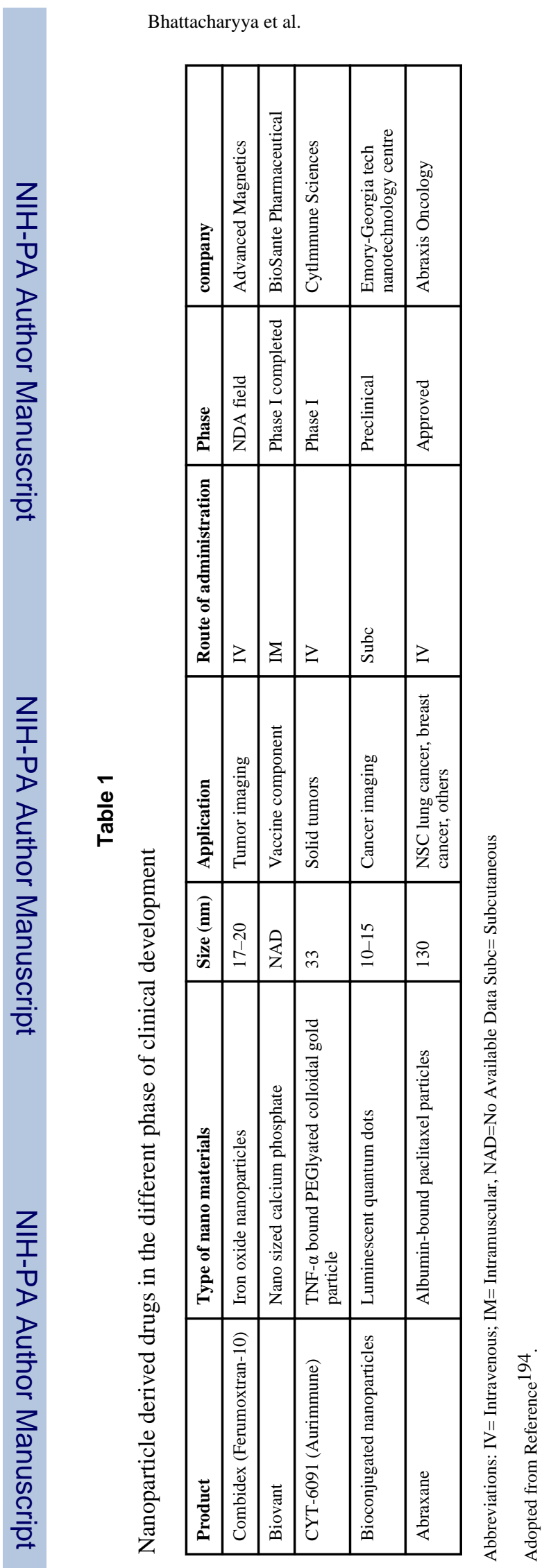

Pharm Res. Author manuscript; available in PMC 2012 February 1. 